NBER WORKING PAPER SERIES

\title{
MONEY, STICKY WAGES, AND \\ THE GREAT DEPRESSION
}

\author{
Michael D. Bordo \\ Christopher J. Erceg \\ Charles L. Evans
}

Working Paper 6071

\author{
NATIONAL BUREAU OF ECONOMIC RESEARCH \\ 1050 Massachusetts Avenue \\ Cambridge, MA 02138 \\ June 1997
}

This paper represents the views of the authors and should not be interpreted as reflecting the views of the Board of Governors of the Federal Reserve System, the Federal Reserve Bank of Chicago, other members of their staff, or the National Bureau of Economic Research. The authors thank Ben Bernanke, Steve Cecchetti, Chris Hanes, Evan Koenig, Robert Kollman, Andrew Levin, Prakash Loungani, Sergio Rebelo, Anna Schwartz, and Michael Woodford for comments on an earlier draft, as well as seminar participants at the Federal Reserve Board, the Federal Reserve Bank of New York, and the NBER Monetary Economics Group. This paper is part of NBER's research programs in the Development of the American Economy, Economic Fluctuations and Growth and Monetary Economics.

(C) 1997 by Michael D. Bordo, Christopher J. Erceg and Charles L. Evans. All rights reserved. Short sections of text, not to exceed two paragraphs, may be quoted without explicit permission provided that full credit, including (C) notice, is given to the source. 
Money, Sticky Wages, and the Great Depression

Michael D. Bordo, Christopher J. Erceg

and Charles L. Evans

NBER Working Paper No. 6071

June 1997

JEL Nos. N12, E32

Development of the American Economy, Economic

Fluctuations and Growth and Monetary Economics

\begin{abstract}
This paper examines the ability of a simple stylized general equilibrium model that incorporates nominal wage rigidity to explain the magnitude and persistence of the Great Depression in the United States. The impulses to our analysis are money supply shocks. The Taylor contracts model is surprisingly successful in accounting for the behavior of major macroaggregates and real wages during the downturn phase of the Depression, i.e., from 1929:3 through mid-1933. Our analysis provides support for the hypothesis that a monetary contraction operating through a sticky wage channel played a significant role in accounting for the downturn, and also provides an interesting refinement to this explanation. In particular, both the absolute severity of the Depression's downturn and its relative severity compared to the $1920-21$ recession are likely attributable to the price decline having a much larger unanticipated component during the Depression, as well as less flexible wage-setting practices during this latter period. Another finding casts doubt on explanations for the 1933-36 recovery that rely heavily on the substantial remonetization that began in 1933 .
\end{abstract}

\author{
Michael D. Bordo \\ Department of Economics \\ Rutgers University \\ New Brunswick, NJ 08903 \\ and NBER \\ bordo@rci.rutgers.edu
}

\author{
Christopher J. Erceg \\ Board of Governors of \\ the Federal Reserve System \\ Division of International Finance \\ 20th and C Streets, NW \\ Washington, DC 20551 \\ ercegc@frb.gov
}

\author{
Charles L. Evans \\ Research Department \\ Federal Reserve Bank of \\ Chicago \\ PO Box 834 \\ Chicago, IL 60690 \\ cevans@frbchi.org
}




\section{Introduction}

A full understanding of the factors which led to the Great Depression in the United States continues to elude economists. Many contributing factors may have been important including the stock market crash of 1929 (Mishkin 1978 and Romer 1990), the nonmonetary effects of banking panics (Bernanke 1983), a dramatic increase in world tariffs (Meltzer 1976 and Crucini and Kahn 1996), adherence to the gold standard (Eichengreen 1992a and Temin 1989), and an autonomous drop in consumption (Temin 1976). Nevertheless, Friedman and Schwartz's (1963) hypothesis, that the failure of U.S. monetary policy to offset bank-panic induced declines in the money supply was the primary cause of the U.S. downturn between 1929 and 1933, probably remains the most widely subscribed explanation. ${ }^{1}$

The recent literature, working within the context of the monetary explanation, has focused on the mechanism by which the monetary collapse was transmitted to the real economy. What is in contention is whether the real effects of the monetary contraction were attributable to nominal wage rigidities (Bernanke and Carey, 1996), to increased bankruptcies associated with debt deflation (Fisher 1933), or to a severe disruption in the process of financial intermediation due to large-scale bank failures (Bernanke, 1983).

Recent empirical research has found support for the hypothesis that monetary shocks operating through a sticky wage channel played an important role in accounting for the Depression in the United States and elsewhere. In an important paper, Eichengreen and

\footnotetext{
${ }^{1}$ Some recent surveys of the Depression period are contained in papers by Bordo (1989); Bordo, Choudhri, and Schwartz (1995); Calomiris (1993); Eichengreen (1992b); and Romer (1993).
} 
Sachs (1985) found that real wages tended to be higher and industrial production lower among countries that remained on the gold standard. These authors interpreted their results as consistent with the sticky wage hypothesis. Insofar as countries that remained on gold experienced comparatively larger price declines, the sticky wage hypothesis predicts that they would also tend to experience larger increases in real wages, and correspondingly larger output contractions. Bernanke (1995) and Bernanke and Carey (1996) corroborated these predictions empirically using panel data on a larger set of countries than the EichengreenSachs study. Bernanke and Carey also tried to assess the extent to which the price decline operated through a sticky wage channel, or through other mechanisms such as debt-deflation. They concluded that "our evidence favors the view that sticky wages were the dominant source of nonneutrality (p. 880)."

Our paper focuses on the ability of the sticky wage hypothesis to explain the Great Depression in the United States over the $1929-36$ period. While the previously mentioned crosscountry regression results serve as an important motivation for our analysis, those findings do not quantify the extent to which the sticky wage channel can account for the magnitude of the Depression and its persistence. Through simulations of a general equilibrium model, our paper provides a quantitative assessment of the extent to which monetary shocks working through the sticky wage channel can account for the severity of the Depression and its duration.

The economy we study has a fairly typical neoclassical structure with a representative agent and capital accumulation. For simplicity, money is assumed to be valued by agents 
through a money-in-the-utility function specification. As always, a contentious part of the analysis is how to introduce monetary nonneutralities: we assume that nominal wages are set in advance, and investigate the implications of two different types of wage-setting mechanisms. The first specification assumes that wages are set in forward-looking Fischer contracts (e.g., Fischer 1977, King 1990, Cho and Phaneuf 1993). The alternative specification assumes that wages are set through Taylor contracts (Taylor 1980). The advantage of the latter specification is that it can potentially accommodate more persistent labor market disequilibrium arising from monetary disturbances, as the nominal wage set in the current period is in part "anchored" by wage contracts in the past that are still in effect.

The model is simulated over the 1929-1936 period by inputting estimates of exogenous innovations to the money growth rate (M1) into the state-space representation of the linearized model. Model simulations of output, hours worked, consumption, and investment are compared to actual data.

Both the Fischer and Taylor contract variants of our model are successful in tracking the downturn in output and hours worked between 1929 and early 1932. For example, both models imply an output decline between the onset of the Depression in 1929:4 and the first half of 1932 that is within a couple of percentage points of the $35 \%$ drop that was observed (in logarithmic percentage terms). The Taylor specification is more successful than the Fischer specification in accounting for the persistence of the downturn in the 1932-33 period. The Fischer specification counterfactually implies that the stabilization in monetary aggregates in 1932 should have generated a strong recovery by the latter part of that year. 
The Taylor specification does better, but it cannot account for the continued drop in output that occurred between early 1932 and early 1933 (most of which was concentrated in 1933:1, the Depression trough). Even so, the Taylor model driven by exogenous money supply shocks can account for $75 \%$ of the output decline (of $44 \%$ ) that occurred between 1929:4 and the first half of 1933. Similarly, the Taylor model does well in tracking the behavior of hours worked and investment through early 1932 , though it misses some of the additional decline in these variables that occurred in the subsequent year. It provides a good characterization of consumption behavior through the entire downturn phase of the Depression.

Four key points emerge from our analysis of the ability of the sticky wage model to explain the downturn phase of the Depression. First, the mechanism through which the sticky wage model predicts the monetary decline would affect the macroaggregates seems consistent with the data: our model does a good job of tracking wage behavior over the period, correctly implying a pronounced rise in the real wage between 1929 and mid-1932, followed by a gradual decline until mid-1933. Second, our model simulations and sensitivity analysis suggest that in addition to sluggish wage adjustment, a largely unanticipated price decline played a significant role in accounting for the severity of the Depression. Our results indicate that the Depression would have been considerably less severe in its real effect, even with an equally large price decline, had a greater component of the price decline been anticipated, or if nominal wages had adjusted more rapidly to the reduction in labor hours. Third, our comparative analysis of the 1920-21 recession further highlights the likely joint importance of the unanticipated character of the price decline and extremely sluggish nominal 
wage adjustment during the 1929-33 period. In the 1920-21 recession, output fell only half as much (in percentage terms) as the Great Depression period, despite similar-sized cumulative declines in the price level. The literature has suggested that a much larger component of the price decline was anticipated during the earlier period and that wages adjusted more rapidly to aggregate demand, two factors that could help explain the different experiences of the two periods. Our simulations indicate that the output differences a.cross the two periods can be rationalized if much of the 1920-21 deflation were anticipated and nominal wages adjusted more rapidly in this earlier period.

Fourth, our analysis of the 1933-36 period casts doubt on Romer's explanation (1992, 1993) of the recovery phase. Romer argues that the recovery was largely attributable to the substantial and sustained increase in monetary aggregates that began in 1933. Our model and Romer's hypothesis both imply a strong recovery in economic activity due to the stimulative effect of the remonetization and its affect on the price level. However, the mechanism through which our model generates a recovery — namely, a fall in real wages is badly at odds with the data. In fact, real wages rose sharply beginning in mid-1933, as nominal wages rose more than prices. The large rise in nominal wages appears to have been largely exogenous in nature, reflecting the implementation of various legislation, including the National Industrial Recovery Act (NIRA). NIRA basically mandated wage schedules for various industries. Thus, while the monetary expansion of 1933-35 presumably mitigated the adverse effects of the nominal wage increases, we conclude that the monetary expansion was not nearly strong enough to lead the U.S. economy out of the Depression. Given that 
other factors, including those emphasized by Bernanke (1983), probably conspired with the real wage increase in order to slow the pace of the economic recovery, it remains for further research to provide a convincing account of the factors that produced the economic recovery from the Great Depression.

The remainder of this paper is organized as follows. Section 2 discusses the basic model and presents the two alternative wage contract structures. Section 3 examines the impulse response functions from a monetary disturbance, while section 4 compares simulations of each model's implications for major macroaggregates to the corresponding data. Section 5 attempts to account for differences in the response of output to similar-sized price declines that occurred in the 1920-21 recession and in the Depression. Section 6 concludes the paper.

\section{The basic model with wage contracts}

The model used to investigate the hypothesis that money operating through a sticky wage channel caused the Great Depression has a fairly standard neoclassical structure. A representative agent makes consumption/investment decisions and portfolio choices in a manner consistent with utility maximization subject to an infinite-horizon budget constraint. The primary departure from a "typical" neoclassical specification is that our model allows for monetary nonneutrality by dropping the assumption of continuous labor-market clearing. Instead, wages are determined by Fischer or Taylor contracts. In the short-run - the period before labor contracts can be renegotiated - households are assumed to supply all labor demanded at the given wage rate, so that the quantity of labor actually hired is determined 
by the demand for labor schedule of the representative firm.

Our rationale in considering two different contract structures is that they provide two rather extreme perspectives on the sticky-wage transmission mechanism. In particular, it is well-known that the Fischer contract specification basically implies that monetary innovations only have real effects over the contract interval, which is assumed to last four quarters in our analysis. By contrast, the Taylor wage contract specification can be parameterized to allow monetary innovations to have effects that persist well beyond the contract interval.

\subsection{Households}

The representative household seeks to maximize a utility functional of the form:

$$
\sum_{t=0}^{\infty} \beta^{t} U\left(c_{t}, \frac{M_{t}}{P_{t}}\right)
$$

where $\beta$ is the discount factor, $c$ is real consumption, $M$ is nominal cash balances at the end of period $t$, and $P$ is the price level. The period utility function is given by:

$$
U\left(c_{t}, \frac{M_{t}}{P_{t}}\right)=q_{1} \ln c_{t}+\left(1-q_{1}\right) \ln \left(\frac{M_{t}}{P_{t}}\right)
$$

To focus attention on the role of nominal wage contracts in determining labor movements, we abstract from the household's labor supply decision by omitting labor from the utility function. As we discuss below, we assume: (1) that the household has a time-invariant, target value of labor hours denoted by $\bar{L}$, and (2) that the process of wage adjustment implied by either of the two contract specifications that we examine is consistent with the household 
supplying this quantity of labor in the long-run. At any point in time, however, labor hours will vary from $\bar{L}$ depending upon variations in the demand for labor. ${ }^{2}$

Households accumulate nominal assets according to the following law of motion:

$$
B_{t}=B_{t-1}+\left(R_{t-1} B_{t-1}+W_{t} L_{t}+J_{t} K_{t}+\pi_{t}+X_{t}\right)-\left(M_{t}-M_{t-1}+P_{t} c_{t}+P_{t} I_{t}\right)
$$

where $J$ is the rental price of capital in nominal terms, $K$ is the capital supplied to firms, $W$ is the nominal wage rate, $L$ is total hours worked, $\pi$ is nominal firm profits, $R$ is the nominal interest rate on bonds, $B$ is nominal bond holdings, $X$ is lump-sum cash transfers from the government, and $I$ is gross real investment. The first term in parentheses in equation (2.3) is household nominal income. Household income consists of interest income on bonds, wage income, income from capital, firm profits, and lump-sum cash transfers from the government. The second term in parentheses is household nominal expenditures, which consists of spending on consumption and investment goods, and on accumulating cash balances.

Households purchase investment goods in order to increase their stock of physical capital (which they in turn rent to firms):

$$
K_{t+1}=(1-\delta) K_{t}+I_{t}
$$

\footnotetext{
${ }^{2}$ We have examined versions of our economy which model endogenous labor supply choices by the household. Those results are qualitatively similar to our findings reported here. By abstracting from the household's endogenous labor supply decision, however, it is clear that we are not attempting to explain the Great Depression with large intertemporal labor supply movements.
} 
The household's optimization problem is to choose $c_{t}, M_{t}, B_{t}, K_{t+1}$, and $\lambda_{t}$ to maximize (2.1), subject to constraints (2.3) and (2.4):

$$
\sum_{t=0}^{\infty} \beta^{t} U\left(c_{t}, \frac{M_{t}}{P_{t}}\right)+\lambda_{t}\left[\begin{array}{c}
\left(1+R_{t-1}\right) B_{t-1}+W_{t} L_{t}+J_{t} K_{t}+\pi_{t}+X_{t}- \\
\left(M_{t}-M_{t-1}+B_{t}+P_{t} c_{t}+P_{t} K_{t+1}-(1-\delta) P_{t} K_{t}\right)
\end{array}\right]
$$

Several observations about the household's decision problem are in order. First, because household labor supply is determined by the labor demand of firms (wage determination is discussed below), $L_{t}$ is not a choice variable. Second, the first-order conditions imply a demand for money function of the double-log form:

$$
\ln \frac{M_{t}}{P_{t}}=-\ln \frac{q_{1}}{\left(1-q_{1}\right)}+\ln c_{t}-\ln \frac{R_{t}}{1+R_{t}}
$$

Thus, the model implies that household consumption, not output, is an argument of the money demand function. Accordingly, positive money supply shocks tend to have smaller effects on the price level to the extent that they induce a rise in real money demand through their stimulative effect on consumption. Third, the model abstracts from fiscal policy considerations: the only role of government is to distribute lump-sum cash transfers to households that it finances by printing money. 


\subsection{Firms}

Firms rent labor and capital services from households at the prevailing nominal wage $W_{t}$ and capital rental price $J_{t}$. Hence, firms solve a static optimization problem of the form:

$$
\max \pi_{t}=P_{t} F\left(K_{t}, L_{t}\right)-W_{t} L_{t}-J_{t} K_{t}
$$

The production function $F(K, L)$ is assumed to be Cobb-Douglas:

$$
F\left(K_{t} L_{t}\right)=K_{t}^{\theta} L_{t}^{1-\theta}
$$

The first-order conditions to this problem give the demand for labor and capital schedules of a representative firm:

$$
\begin{gathered}
F_{2}\left(K_{t}, L_{t}\right)=\frac{W_{t}}{P_{t}} \\
F_{1}\left(K_{t}, L_{t}\right)=\frac{J_{t}}{P_{t}}
\end{gathered}
$$

\subsection{Wage determination}

The model is completed by describing the stochastic processes governing the evolution of wages and the supply of money. The wage contract structures discussed below both imply that monetary shocks affect real wages in the short-run, and hence the labor demand and output supplied by firms, because prices basically respond immediately to such shocks, while wages take some time to fully adjust. 


\section{3.1. Fischer contract specification}

In our set-up, Fischer wage contracts are arrangements in which the nominal wage prevailing $k$ periods in the future is set in the current period. At the contracted wage, households expect to work a time-invariant quantity of hours, which we denote by $\bar{L}$. A natural choice for $\bar{L}$ is the average share of the time endowment spent working, typically calibrated to be in the range of thirty percent. Given that labor hours are demand-determined, the contracted nominal wage, set at time $t$ to apply in period $t+k$, equals the expected value marginal product of labor of a representative firm at $t+k$, evaluated at the time-invariant hours worked $\bar{L}:{ }^{3}$

$$
W_{t+k}=E_{t}\left\{P_{t+k} F_{2, t+k}\left(K_{t+k}, \bar{L}\right)\right\}
$$

Thus, the nominal wage is set so that the real wage that is expected to prevail when the contract takes effect is expected to allow hours worked to equal its long-run average level. Although a monetary shock can cause hours worked to deviate from its long-run level during the subsequent $k-1$ periods, nominal wages fully adjust to the new post-shock price level after $k$ periods. Money is virtually neutral after $k$ periods, except for the small effect of capital stock adjustment that occurs along the transition.

The approximate neutrality of monetary shocks beyond the length of the contract period imposes a strong a priori constraint on the ability of monetary shocks to explain business cycle fluctuations, at least if reasonable assumptions are made about the length of the contract interval. We assume that wage contracts last four quarters. Rather than attempting to

\footnotetext{
${ }^{3}$ This assumes certainty equivalence.
} 
derive greater persistence in the real effects of monetary innovations by stretching the length of the contract interval beyond a year - which would seem to be very difficult to justify empirically, given the generally weak power of labor unions at the onset of the Depression - we consider also the alternative staggered overlapping wage contract scheme suggested by Taylor (1980).

\subsubsection{Taylor overlapping wage contracts}

In the Taylor contract specification, the labor force may be regarded as divided into equalsized cohorts of workers, with the number of cohorts equal to the length of the contract period. With the contract interval set equal to four quarters, this means that there are four cohorts of workers. During the beginning of each quarter, one of the four cohorts agrees to a nominal wage that it will receive for the following year. For example, cohort A agrees to a wage $x_{t}$ during the winter and this process is repeated by the other cohorts during the subsequent three quarters of the year. Following Taylor (1980), the contract wage $x_{t}$ depends on the geometric average wage $W_{t}$ of all cohorts in the economy that will prevail over the (four-quarter) life of the contract, as well as on the evolution of hours worked. Specifically, the contract wage of the cohort renegotiating its wage at time $t$ is given by:

$$
\ln \left(x_{t}\right)=\phi_{0}\left(\ln \left(W_{t}\right)+\gamma\left(\bar{L}-L_{t}\right)\right)+E_{t}\left\{\begin{array}{c}
\phi_{1}\left(\ln \left(W_{t+1}\right)+\gamma\left(\bar{L}-L_{t+1}\right)\right)+\phi_{2}\left(\ln \left(W_{t+2}\right)+\right. \\
\left.\gamma\left(\bar{L}-L_{t+2}\right)\right)+\phi_{3}\left(\ln \left(W_{t+3}\right)+\gamma\left(\bar{L}-L_{t+3}\right)\right)
\end{array}\right\}
$$


where $\gamma<0$ and $W_{t}$ denotes the geometric average wage of all cohorts in the economy at time $t$

$$
W_{t}=x_{t}^{\phi_{0}} x_{t-1}^{\phi_{1}} x_{t-2}^{\phi_{2}} x_{t-3}^{\phi_{3}}
$$

where we take $\phi_{i}=0.25$, for all $i$. With $\phi_{i}=0.25$, repeated substitution of (2.13a) into (2.12) yields:

$$
\ln \left(x_{t}\right)=E_{t}\left\{\begin{array}{l}
\frac{1}{12} \ln \left(x_{t-3}\right)+\frac{1}{6} \ln \left(x_{t-2}\right)+\frac{1}{4} \ln \left(x_{t-1}\right)+\frac{1}{4} \ln \left(x_{t+1}\right)+\frac{1}{6} \ln \left(x_{t+2}\right)+ \\
\frac{1}{12} \ln \left(x_{t+3}\right)+\gamma \sum_{k=0}^{3}\left(\bar{L}-L_{t+k}\right)
\end{array}\right\}
$$

As in Taylor (1980), two features of equation (2.14) are noteworthy. First, contract wages have an inertial or backward-looking component; that is, past contract wages appear in the equation. This inertial component reflects in part that the current contract wage depends on the current average wage across all cohorts, which itself is an average of contract wages set in the past that are still in effect. This inertial component of wages tends to "anchor" the current wage. Second, the only channel forcing nominal wages to adjust are current and future expected labor hours. Accordingly, the parameter $\gamma$ is of crucial significance: given the structure of dependence between the current contract wage and past and future wage rates, it controls how quickly wages adjust to changing labor market conditions. Low absolute values of $\gamma$ imply comparatively slow adjustment of nominal wages - and, as shown in the next section, allow the model to account for much more persistent real effects of monetary shocks than the Fischer specification. 


\subsection{Money stock evolution}

The model economy abstracts from a banking sector and the endogenous creation of money. Thus, the stock of money is assumed to be exogenously determined. The growth rate of the stock of money is assumed to follow a first-order autoregression of the form:

$$
\begin{aligned}
g_{t+1} & =g_{0}+\rho g_{t}+\sigma \varepsilon_{t+1} \\
g_{t} & =\ln \left(M_{t}\right)-\ln \left(M_{t-1}\right)
\end{aligned}
$$

where $\varepsilon_{t+1}$ is independent and identically distributed (i.i.d.) $N(0,1)$.

The assumption that the money growth process evolved exogenously over the Depression period seems reasonable given the focus of the paper - to derive the consequences of the monetary decline (and subsequent expansion) for real activity, irrespective of the sources of the monetary decline. In particular, the mechanism through which money is posited to affect real activity in the model (the sticky-wage channel) means that equal-sized shocks to the quantity of money that might have been generated from very different sources should have similar effects on real activity. Some candidate alternative sources include the effect of Federal Reserve open market operations on the base, or the effect of bank panics on the money multiplier. Our formulation is in accordance with the recent literature investigating the sticky wage channel. This literature has mainly emphasized how various shocks were important because of their effect on money and the price level, and not because they had a 
large direct effect on activity (Bernanke and Carey, 1996). ${ }^{4}$

\subsection{Calibration and Solution Method}

The model's free parameters include the technology parameters $\theta$ and $\delta$, the utility function parameters $\beta$ and $q_{1}$, and the money supply evolution parameters $\rho$ and $\sigma$. The model is assumed to hold at a quarterly frequency.

The capital share parameter $\theta$ is set equal to 0.3 and the quarterly depreciation rate to 0.02 , in the range of typical estimates of these parameters derived from postwar data. The discount factor $\beta$ is set to 0.99 , implying an annual real interest rate of about four percent. The share parameter $q_{1}$ is determined from the household's steady state money demand function, under the assumption that velocity equals one. In this case, equation (2.6) implies:

$$
\frac{q_{1}}{1-q_{1}}=\frac{1+\bar{R}}{1+2 \bar{R}}
$$

where $\bar{R}$ is the steady state value of the nominal interest rate. Because it seems reasonable to roughly define the steady state value of a variable as its average value over a "typical" period, the steady state value of $\bar{R}$ is taken to be its average value over the 1921-28 period. Using the interest rate on three-month commercial paper (taken from the Balke-Gordon data appendix of The American Business Cycle, 1986) as a proxy for $\bar{R}$, the average value is $1.2 \%$

\footnotetext{
${ }^{4}$ On the other hand, the failure of our model to account for the duration of the Depression period might argue for incorporating an endogenous theory of money supply determination, so that various shocks that "indirectly" affected real activity through their effect on money and the price level might also exert direct effects of varying magnitude. For example, bank panic shocks that induced declines in the money multiplier and hence affected real activity through the channel outlined in our model might have an additional effect to the extent that bank closures associated with the panics raised the cost of financial intermediation.
} 
at a quarterly rate, implying that $q_{1}=0.987 . .^{5}$ Similarly, the money supply parameters $\rho$ and $\sigma$ are estimated by using observations on the growth of $\mathrm{M} 1$ over the same period. Fitting a first-order autoregression to M1 growth implies that $\rho=0.33$ and that $\sigma=0.012$, where $\sigma$ is in units of quarterly rates of change. ${ }^{6}$ A discussion of the implications of our specification of the money supply rule and sensitivity of our results to these parameter choices is provided below.

The approximate dynamic behavior of the model is obtained by first linearizing the appropriate nonlinear stochastic difference equations around the steady-state values of the state variables, and then applying the method of Blanchard and Kahn (1980) ${ }^{7}$ The equations determining the evolution of the state variables include the wage equation ( 2.11 for the Fischer contract case or 2.14 for the Taylor contract case) and the household's first-order equations for real balances and capital, subject to the aggregate resource constraint.

\section{Impulse Response Functions}

Figures 1-7 plot the model's impulse response functions (IRF) to a one-standard deviation, positive innovation in the growth rate of money for the Fischer wage contracts model and two parameterizations of the Taylor contracts model. In one Taylor contracts parameterization, nominal wages respond relatively slowly to deviations in labor hours from their average level

\footnotetext{
${ }^{5}$ The annualized nominal rate of interest is $4.8 \%$. Our discount factor implies a $4 \%$ annualized real rate of interest. Inflation varied over this period between slightly positive and negative rates.

${ }^{6}$ The basic results discussed below are not particularly sensitive to substituting the growth rate of M2 for M1. The M1 data are taken from Friedman and Schwartz (1963).

${ }^{7}$ Because the money stock grows at a nonzero rate on average, the state variables representing nominal magnitudes - namely the nominal wage and price level - are scaled by the stock of money so that the system is stationary in the transformed variables.
} 
$(\gamma=-0.1)$; and another, wages respond much more rapidly $(\gamma=-0.5)$. In all of these figures, the innovation occurs in time period 1.

Figure 1 plots the IRF of the price level (for the Fischer and Taylor contract parameterizations). On impact the model predicts that a positive innovation in the stock of money increases real money demand by less than the increase in the money supply. This innovation leads to an immediate increase in the price level relative to its baseline path. Following this initial jump, the figure indicates that the price level actually declines somewhat in the shortto medium-term. The price level decline reflects the rising profile of consumption and its influence on real money demand (from equation 2.6). Nevertheless, prices continue to be higher than before the money innovation.

The highly front-loaded response of the price level implies that the price level increases associated with positive money innovations are largely unanticipated. This implication is not particularly sensitive to our choice of the money growth persistence parameter $\rho$ : in order for money growth innovations to lead to a persistent change in the rate of growth of the price level, $\rho$ must be in the 0.9 range or higher (about three times our estimate). The figure also shows that the price level IRFs do not vary substantially across the three specifications, though the price level effects of monetary innovations are smallest in the near to medium term in the Taylor specification with low $\gamma=-0.1$. In this contract specification, a one standard deviation monetary innovation has the largest effects on consumption and real money demand.

Figure 2 plots the IRF of the nominal wage. In the Fischer contract case, nominal wages 
do not respond at all during the first four quarters following a shock, but then jump to a level consistent with steady-state labor hours. The Taylor contract specifications are consistent with a gradual adjustment of nominal wages, and the speed of adjustment varies directly with the absolute value of the parameter $\gamma$.

Figures 3 and 4 plot the IRFs of the real wage and hours worked, respectively. In the Fischer case, real wages remain substantially below their equilibrium level until four quarters after the shock, at which point the real wage jumps to a level slightly above its steady-state level (due to the above steady-state capital stock level). Correspondingly, when real wages are unusually low, hours worked are much higher than their steady-state level; hours worked fall to their steady-state level when real wages increase. The behavior of hours worked clearly reflects the assumption that labor hours are determined by a basically static labor demand schedule.

For the Taylor specifications, the IRFs of the real wage and hours worked are qualitatively similar to those of the Fischer model, except that the adjustments to the steady-state are relatively smooth. Moreover, real wages adjust much more slowly as the absolute value of $\gamma$ declines, implying that hours worked remain above their steady-state level for a longer period. Clearly, the IRFs indicate that the Taylor model with low absolute values of $\gamma$ produce more persistent monetary nonneutralities; and this is holding the contract length fixed.

Figures 5 through 7 plot the IRFs of output, consumption, and investment, respectively. Since the capital stock adjustment tends to be quite modest, the output IRFs basically 
mirror the corresponding hours worked IRFs. For consumption, the peak response tends to be considerably smaller than that of output, reflecting the transient nature of the shock's impact on income. The absolute magnitude of the consumption response is largest in the Taylor model with a low absolute value of $\gamma$, since the effects on household income are largest in this case. The strong response of investment in each of the cases reflects the household's desire to smooth consumption by investing in productive capital.

\section{Comparisons of Model Simulations with Data over the 1929-36 period}

In this section, time series plots of output, consumption, investment, and hours worked generated from model simulations are compared with corresponding data. The objective is to provide a quantitative assessment of the ability of the sticky wage model (including both the Fischer and Taylor contract specifications) to explain the behavior of major macroaggregates during the Great Depression period.

\subsection{Data}

The data on output, consumption, and investment used in the comparisons are primarily based on the quarterly national income accounts data constructed by Balke and Gordon (1986). Some effort is required in order to fit actual national income accounts data into the much simpler accounting identity imposed in the model, because the model does not 
specify either an external or a government sector ${ }^{8}$. Output is identified as real GDP from the NIPA. The consumption component in the model is equated with private spending on nondurable goods and services plus a measure of public consumption spending. The public consumption series is derived from subtracting a measure of government investment spending from government purchases; government investment spending is based on interpolating annual data that appears in the BEA publication Fixed Reproducible Tangible Wealth in the United States. Finally, investment is defined as a residual between output and our measure of consumption. Although net exports are included in this measure of investment, this seems reasonable given that the model defines investment as foregone consumption. The hours worked series is derived from multiplying total employment by the average length of the workweek in the manufacturing sector. The employment data are quarterly and from the Bureau of Labor Statistics. Aggregate workweek data are not available quarterly, so we use the average hours worked per week in the manufacturing sector from the National Industrial Conference Board (Beney 1936). All of these data are defined in per capita terms.

Our comparisons also involve nominal and real wages. The nominal wage series represents an average of payroll wages in 25 manufacturing industries. As with the workweek data, nominal wage data are not available at an aggregate level outside of manufacturing. These data were compiled by the NICB and are available for the period 1920:3 to 1936:2 (Beney 1936). Our real wage series is derived by deflating this nominal wage series by the GDP deflator (from Balke and Gordon 1986). ${ }^{9}$

\footnotetext{
${ }^{8}$ In other words, output equals consumption plus investment.

${ }^{9}$ The results reported below are essentially unchanged when we considered an alternative measure of
} 


\subsection{The downturn phase of the Great Depression}

The model is simulated over the 1929:4-1936:4 period by inputting estimates of money growth innovations over that period into the state-space representation of the model. The money growth innovations are derived from the money supply evolution equation using data on M1 growth and the parameter estimates of the M1 growth process (equation 2.15). The simulations also assume that all model variables (including the growth rate of M1) were at their steady-state level in 1929:3. Because the simulated data are represented in "percent deviation from steady state" form, historical data are represented in a comparable form by constructing each series as a logarithmic percentage deviation from its 1929:3 level.

Estimates of the innovations to money growth are plotted in Figure 8. It is evident from the figure that our parameterization implies a series of large negative innovations to money growth beginning in 1929:4. In fact, these innovations are very close to the actual rate of money growth, given the low value of the autoregressive parameter. Our model implies that these negative money growth innovations should have led to a series of largely unanticipated declines in the price level, as shown below.

Figures 9-12 display the effects of the price decline on output, hours worked, consumption, and investment implied by the Fischer wage contract, and also the data for these variables. It is clear from the simulated data that the negative shocks to money growth over the 1929-32 period were sufficiently large to account for a massive contraction in all of these macroaggregates. Given its simple structure, the model does reasonably well from a

nominal wages that controls for changing industry composition. This data was provided by Chris Hanes; see Hanes (1995a, 1995b). 
quantitative perspective in fitting the observed path of output and hours worked until early 1932. For example, the model implies a 32 percent decline in output relative to its 1929 level by $1932: 1$, which is very close to the 35 percent decline that was observed.

However, the model performs poorly along several dimensions. Because the model does not allow monetary shocks to affect hours worked beyond the assumed length of wage contracts (one year), the path of hours basically traces the path of money innovations except for a short lag (see Figure 10). As a result, the model incorrectly implies that the stabilization of monetary aggregates in the spring of 1932 should have led to a substantial rise in hours worked. Also, the sustained remonetization that occurred during the 1933-1936 period should have led to an extremely strong expansion in hours worked beginning in mid-1933. Because the path of output is largely determined by the path of hours worked, the model is far off the mark in its predictions of a substantial recovery in output in 1932 and a major boom by late 1933. Finally, it is evident from Figure 11 that the model substantially underpredicts the magnitude of the fall in consumption that occurred during the Depression downturn. This reflects the Fischer model's implication that monetary shocks have a very transient effect on permanent income.

It is clear that accounting for the persistence of the downturn in output, hours, consumption, and investment within a purely monetary framework requires that monetary shocks exert considerably more persistent real effects than is afforded by the Fischer contract specification. The IRFs suggest that the Taylor model with sufficiently sluggish wage adjustment (i.e., a low absolute value of $\gamma$ ) may provide a better account of the behavior of these 
macroaggregates after early 1932. Accordingly, we simulate the Taylor model below choosing $\gamma=-0.1$, which implies IRFs that are considerably more persistent than in the Fischer specification (refer again to Figures 5-7). Some justification for this parameter choice is provided below.

Figure 13 compares the data on output based on this parameterization of the Taylor model with the corresponding simulated series over the 1929:4-1936:4 period (refer to the line marked "without MD shocks" in Figures 13-16, which distinguish these simulations from a variant that allows for money demand shocks considered below). The model tracks the output downturn extremely well through early 1932. The model does much better than the Fischer specification in accounting for the persistence of the output downturn between early 1932 and mid-1933. The Taylor specification cannot, however, account for the continued output decline that occurred between early 1932 and mid-1933; in this case, the model predicts a slight recovery in output over that period. Despite this shortcoming, the model still appears to do reasonably well in accounting for the magnitude of the output decline experienced at the Depression trough, implying an output decline of 30 percent in the first half of 1933 (from its 1929:3 level), compared to the 44 percent decline observed.

A much more serious shortcoming of the model is its significant overstatement of the recovery's strength beginning in late 1933 or early 1934. In particular, it predicts that the remonetization begun in late 1933 should have allowed output to recover rapidly to its pre-Depression level and surpass it by the second half of 1934 .

As seen in Figure 14, the model provides a fairly good characterization of the behavior 
of hours worked during most of the downturn phase of the Great Depression. However, the model significantly underpredicts the contraction in hours worked that occurred between early 1932 and early 1933 . The most important failure of the model is its implication of a rapid recovery in hours worked following the remonetization that began in late 1933. As with the output implications, the model predicts that hours worked should have returned to their pre-Depression level by mid-1934. However, actual hours worked recovered very slowly between 1933 and 1935, and remained about 40 percent below its 1929:3 level at the end of 1935.

The model basically captures the observed path of consumption (Figure 15), both with respect to its timing and magnitude. However, it underpredicts the magnitude of the decline to a modest degree. The model implies a decline in consumption of about 15 percent at the trough, compared to the 19 percent decline observed. Relative to the Fischer model, the Taylor model's prediction of a much more rapid and deep decline in consumption over 1929-33 reflects the more persistent monetary nonneutralities in this case.

The model's ability to track investment - shown in Figure 16 - is similar to its performance in accounting for output and hours worked. The model does well through early 1932, but implies a slight recovery of investment over the subsequent year, in contrast to actual investment spending, which declined somewhat further until reaching a trough in 1933:1. Again, a much more serious shortcoming of the model is its prediction of a major boom in investment spending in the second half of 1933.

Figure 17 indicates that our model does well in accounting for the observed decline in 
the price level through the early part of 1932 , though it does understate the continued sharp price level declines that occurred over the following year. The failure of our simple model to account fully for the observed price level decline over that period might in part reflect shocks to the money demand function that caused the price level to decline by more than would be implied by the behavior of the money stock alone.

\subsection{Incorporating money demand shocks into the analysis}

Given the crucial role of price level changes on real activity in our model, it seems important to investigate whether the model's failure to account fully for the price decline might also weaken its ability to account for the continued downturn in major macroaggregates that occurred between early 1932 and early to mid-1933. Accordingly, we modified the model slightly to allow for money demand shocks $\sigma_{t}$ as well as money supply shocks. The preference specification (2.2) was reformulated as:

$$
U\left(c_{t}, \frac{M_{t}}{P_{t}}\right)=q_{1} \ln c_{t}+\left(1-q_{1}\right) \sigma_{t} \ln \left(\frac{M_{t}}{P_{t}}\right)
$$

Figures 13-16 also display the simulations of the model over the sample period 1929:31936:4 when both money supply and money demand shocks are input into the state-space representation. The money supply shocks are the same as discussed above. The money demand shocks are measured to match exactly the model's implied price level path with the actual price level data. The simulations labelled "w/ money demand (MD) shocks" 
correspond to this case. ${ }^{10}$

It is evident from the figures that allowing for money demand shocks does account slightly better for the magnitude of the downturn in macroaggregates, particularly in the early 1932-early 1933 period. However, the effects of these changes in the specification are not particularly large. For example, the model with money demand shocks implies an output decline of about 34 percent in 1933:Q1 from its pre-Depression level, compared to the 30 percent decline implied by the model that does not allow for money demand shocks.

Summarizing our results thus far, and temporarily focusing on the downturn phase of the Depression, the sticky wage model seems to provide a good characterization of the behavior of major macroaggregates through early 1932 . The model does, however, seem to understate the subsequent decline in real activity that occurred between early 1932 and early 1933, even in our preferred specification that exactly matches the price level decline. The inability of a purely monetary model to explain the downturn fully may reflect the fact that other "supply side" factors, including the effects of bank panics and debt deflation, contributed noticeably to the output decline, particularly in the $1932-33$ period. However, it is still interesting that the sticky wage model appears to account for roughly three-quarters of the observed output decline of 44 percent at the Depression trough. Moreover, figures 18 and 19, which examine

\footnotetext{
${ }^{10}$ To identify a time series for $\sigma_{t}$, we assume that $\sigma_{t}$ is a random walk and its innovations are uncorrelated with the innovations in the money growth process. The money demand shock innovations are identified by comparing the state space representation for $\Delta P_{t}^{M o d e l}$ and the actual data for $\Delta P_{t}^{\text {Data }}$. In particular, $\Delta P_{t}^{M o d e l}-\Delta P_{t}^{\text {Data }}$ depends upon current and lagged endogenous state variables, lagged money growth rates, the money growth innovation, and the money demand innovation. Since we have already identified a time series for the money growth innovations, this determines the money demand innovation. The assumption that the money supply and demand innovations are uncorrelated may appear extreme. But allowing for even significant cross-correlation and autocorrelation in the shock processes (e.g., allowing money supply shocks to accommodate changes in money demand) has very little effect on the behavior of the real and nominal variables depicted in the figures.
} 
the model's implications for real and nominal wages, provide important evidence in support of the sticky wage channel as a cause of the Great Depression. The figures suggest that the mechanism in the model that accounts for the downturn in the macroaggregates - namely, a rise in real wages as nominal wages fell more slowly than the price level - is broadly consistent with the data (at least over the downturn phase of the Depression). ${ }^{11}$

The model accounts extremely well for the rise in real wages that occurred through mid1932, and the modest decline in real wages over the subsequent year. The model's ability to account for persistent real effects on the macroaggregates is not achieved by assuming "excessively sluggish" nominal wage behavior. Our parameterization of $\gamma=-0.1 \mathrm{fits}$ nominal wages well over the 1929:3-1933:2 period, and in fact is the value of $\gamma$ that allows the model to fit observed nominal wage behavior as closely as possible in a least-squares sense.

\subsection{The recovery phase of the Great Depression}

Turning to the recovery phase of the Depression, it is clear that the sticky wage model provides a poor fit. The model implies that the remonetization that began in 1933 should have generated a much more rapid recovery than what actually occurred. It is tempting to try to provide a better fit of the recovery phase of the Depression by forcing monetary innovations to have more persistent effects on real activity. This would be the case if nominal wages responded even less to economic activity, through lower absolute values of $\gamma$. As shown in

\footnotetext{
${ }^{11}$ Figures 18 and 19 are derived from the Taylor model that includes money demand shocks (and hence fits the price level in figure 17 exactly). The version of the model that does not include money demand shocks has quite similar implications for real wage behavior as is shown in figure 18. This similarity accounts for why the two specifications have similar implications for other real variables, though the model with money demand shocks fits observed real wage behavior slightly better.
} 
figure 20, assuming that $\gamma=-0.03$ allows the model to provide a somewhat better account of the behavior of output during the slow recovery. The model also accounts somewhat better for the depth of the downturn in 1932 and early 1933. Corresponding simulations for consumption, hours, and investment also indicate a modest improvement in fit (these results are not displayed).

But an examination of wage behavior over the recovery phase of the Depression suggests that it is not reasonable to attempt to rescue a sticky wage explanation for the recovery by considering lower absolute values of $\gamma$. This is because the sticky wage model fails dramatically on two important features of the recovery phase. First, in the absence of other shocks, the sticky wage model predicts that the recovery should have occurred as declining real wages encouraged an expansion in labor hours worked. But as figure 18 shows, real wages rose sharply beginning in 1933:3, increasing by 20 percent between 1933:3 and 1934:2. As indicated by comparing figures 17 and 19 , real wages rose despite a marked increase in the price level associated with remonetization, as nominal wages rose much more sharply than prices. Second, the model's implication of a strong recovery in hours worked leading the recovery is also inconsistent with the data. Returning to figure 14, observed hours worked recovered much more tepidly than predicted by the model - and much more slowly than total output, as seen by the behavior of actual output and hours worked in figures 13 and 14. Hours worked remained 35 percent below its pre-Depression level as late as the end of 1936, while output had recovered to within 10 percent of its pre-Depression level.

The behavior of real wages and hours worked during the recovery phase of the Depression 
suggests that the rapid run-up in wages beginning in mid-1933 played a key role in dampening the pace of the recovery. The rise in wages is difficult to explain given the high unemployment rates of the period, as has been noted by others. The sharp increases in nominal wages seem to be attributable to various legislation, particularly the NIRA, that became effective in mid-1933 (Weinstein 1981). This legislation essentially set wage schedules for a broad set of industries. The fact that most of the nominal wage increase occurred over a three month period in 1933 - nominal wages rose by 19 percent between July and October — suggests the fiat nature of the wage jump, though increased union power beginning in the early $1930 \mathrm{~s}$ may have also contributed to upward pressure on nominal wages. Other factors in addition to the real wage hikes probably delayed the recovery. For example, Bernanke (1983) has emphasized that widespread bank failures during the period may have exerted a strong contractionary impact, beyond their direct effects on monetary aggregates, by raising the cost of credit intermediation.

Thus, while the sustained monetary expansion that began in 1933 undoubtedly helped ameliorate some of the contractionary effects of the nominal wage hikes and other factors, we conclude that the monetary expansion was not nearly strong enough to explain the recovery. Although providing an account of the key factors that contributed to the recovery is beyond the scope of this paper, it is interesting to note that recent literature has suggested that productivity improvements may have played a substantial role in the recovery. There is some industry evidence that productivity increased markedly in the recovery phase of the Depression because of shake-outs of inefficient producers. For example, Bresnahan and Raff 
(1993) find that automobile production by 1935 had returned to its 1929 level, although there was a considerable change in the mix of producers. Most of the increase in output from very depressed levels in 1933 occurred through an expansion of establishments that had relatively high productivity levels in 1929 , and to a lesser extent by entry of new firms that had a similarly high level of efficiency (measured by output per worker).

This industry level evidence is supported at a more aggregate level in recent work by Cecchetti and Karras (1994). These authors, using various sets of restrictions to identify their vector autoregressions, find that supply shocks accounted for a large fraction of output growth during the recovery period of the Depression. While this evidence is suggestive that supply shocks may have played an important role in offsetting the other contractionary effects of the real wage hikes, providing a fuller explanation for the delayed economic recovery of the 1930s clearly remains an important topic for future research.

\section{Contrasting the Great Depression and the 1920-21 recession}

Our results above suggest that a relatively simple model driven by monetary shocks operating through a sticky wage channel can account surprisingly well for the behavior both of the expenditure components of GDP and of wages over the downturn and bottoming out phases of the Great Depression, 1929:3-1933:2. However, it is useful to draw attention to two factors that play an important role in the model's ability to account for the severity of the Depression. These factors include: (1) the unanticipated nature of the price level decline, and (2) sufficiently sluggish wage adjustment that allows monetary shocks to exert extremely 
persistent real effects. Our analysis below, however, suggests that these two factors were not as important in the early 1920s.

\subsection{9-33}

Our model's implication that the price level decline was largely unanticipated - a feature evident in the highly front-loaded IRFs of the price level from monetary shocks - tends to maximize the real effects of a given-sized decline in the price level. Specifications in which a larger fraction of the price decline is anticipated produce smaller real effects. For example, if a future price decline is anticipated several quarters in advance, nominal wages would begin adjusting downward sooner in response to expected future reductions in the quantity of labor hours that firms will demand. Consequently, real wages will not rise as much when the price level decline is anticipated.

To assess the quantitative significance of this, figure 21 compares the behavior of the simulated path of output derived from the Taylor model above (in Figure 13) with the output path derived under the assumption that the price decline was fully anticipated as of 1929:3. The model's implications from this perfect foresight simulation are obtained by solving the Taylor contracts component of the model, assuming that agents also have perfect foresight about the actual path of the capital stock. Specifically, the average wage $W_{t}$ is defined by equation (2.13a), and is a geometric average of the contract wages $\left\{x_{t}, x_{t-1}, x_{t-2}, x_{t-3}\right\}$. Substituting the contract wages into (2.9), and log-linearizing yields a linear relationship between the logarithms of $x_{t}, x_{t-1}, x_{t-2}, x_{t-3}, P_{t}, K_{t}$, and $L_{t}$. Solving this relationship for $L_{t}$, 
the only unknown variables are the contract wages since $P_{t}$ and $K_{t}$ are assumed to be known under the perfect foresight assumptions. Substituting this solution for $L_{t}$ into the Taylor contracts equation (2.14) yields a single dynamic equation for the contract wage $x_{t}$ in terms of past and future contract wages, as well as current and future price levels and capital stocks. Given the solution for $x_{t}$, the average wage $W_{t}$ and labor hours $L_{t}$ are determined; the production function (2.8) determines output. ${ }^{12}$

It is evident that these "polar opposite" assumptions, about the degree to which the Depression's price decline was anticipated, lead to substantial differences in the predicted output decline. The model suggests that if the future price level decline during the Depression became fully anticipated in 1929, output would have contracted only about 24 percent even if the capital stock declined as sharply as actually occurred, compared to 34 percent in the model in which the price decline was unanticipated. ${ }^{13}$ To the extent that perfect foresight about deflation would have truly ameliorated the data's fall in the capital stock, the output decline implied by the perfect foresight simulations would be somewhat smaller.

We interpret the existing empirical evidence as offering support for the hypothesis that at least a substantial component of the price decline during the Depression was unanticipated. In particular, the magnitude of the price decline was unprecedented in the peacetime

\footnotetext{
${ }^{12}$ To simulate the evolution of $x_{t}$ from a point in time, initial values of the past contract wages and future paths of the price level and capital stock are required. When we say that the price decline was fully anticipated as of 1929:3, we assume that: (1) the initial 1928:4-1929:3 contract wages $\left\{x_{t}, x_{t-1}, x_{t-2}, x_{t-3}\right\}$ equal their steady state values; and (2) any infinite-sums of discounted current and future price levels and capital stocks are well-approximated by their five-year finite discounted sums of future values. On this latter assumption, our calculations were qualitatively robust to truncating the relevant infinite sums at three or four-year horizons.

${ }^{13}$ These simulations are conducted using the same wage adjustment parameter, $\gamma=-0.1$.
} 
history of the United States, and it followed an eight year period of price stability (Friedman and Schwartz, 1963). This suggests that a large fraction of the decline was unanticipated. Hamilton (1992) provides more formal evidence that a large component of the deflation was unanticipated, especially in the first two years of the downturn. Hamilton examines the time series behavior of commodity futures prices and concludes that the market believed that prices would remain stable or rise during most of the Depression's downturn. ${ }^{14}$ Of course, the specific implication of our model that the price decline was completely unanticipated is subject to debate (see Cecchetti, 1992). Still, the important conclusion to be drawn is that the real effects of the price decline predicted by our model depend directly on the extent to which the price decline was unanticipated. Thus, if the price decline was largely unanticipated, the real effects would be large and close to those shown in our simulations. However, if the price decline were largely foreseen, the sticky wage model would have much more difficulty explaining the magnitude of the downturn without reference to other factors.

A second important factor is that wage adjustment in the model must be sufficiently sluggish for monetary policy to have highly persistent effects. This is evident from our comparison of the Fischer and Taylor contract specifications above. In particular, in order to account well for the depth of the downturn, monetary shocks must have real effects that are somewhat longer than the one year period implied by our specification of the Fischer contract model. This holds despite the fact that the model basically allows contractionary monetary shocks to exert maximal effects on output for a given level of wage sluggishness

\footnotetext{
${ }^{14}$ Also see Evans and Wachtel (1993) on this point.
} 
(an implication that the price level decline was unexpected). However, the fact that our parameterization of wage adjustment fits the behavior of both real and nominal wages quite well provides support for our specification.

\subsection{0-21: a puzzling interpretation}

While the unanticipated character of the price decline and sluggish wage adjustment appear important in accounting for the severity of the Depression, these same factors do not appear to explain why the output decline during the 1920-21 recession was much less severe than

during the Great Depression. After all, prices declined by roughly the same cumulative magnitude during these two episodes.

Figures 22 and 23 compare the price decline that occurred during the 1920-21 period with the decline that occurred during the Great Depression. The price level in these figures is represented as a percentage deviation from its 1919:1 and 1929:3 level, respectively. The most striking feature of the figure is that the price decline during the 1920-21 recession was initially much sharper than what occurred during the early downturn phase of the Great Depression. In particular, the price level fell 24 percent between 1920:2 (when the price level reached an interwar peak) and 1921:2. Between 1929:3 and 1931:2 the price level fell by only 12 percent. Friedman and Schwartz (1963) note that the price decline in 1920-21 was the steepest price decline experienced in the United States since at least the early aftermath of the Civil War, and perhaps was the largest that ever occurred in the United States.

Figure 22 indicates that output contracted sharply beginning in 1920:1, and fell by 17 
percent over the subsequent year - slightly larger than the 14 percent decline that occurred during the first year of the Depression (figure 23). However, the subsequent behavior of output shows a major difference between the two periods. Output rebounded strongly from its cyclical trough in the 1920-21 downturn beginning in 1921:2, reaching its pre-recession level by mid-1923, in strong contrast to the persistent output declines that occurred in 1931-33.

If the price level decline that occurred in 1920-21 was in fact largely unanticipated, and wages adjusted as sluggishly as in our parameterization of the Great Depression period, then the price decline of 1920-21 — based on our earlier results - should have generated a massive and persistent depression. This intuition is confirmed in Figure 24, which indicates that output should have contracted by almost 50 percent in logarithmic terms (or by almost one-third from its level in 1920:2). The simulation in Figure 24 is derived using essentially the same parameterization of the Taylor contracts model that we considered for the 1929-36 period. The only difference in specification is our inclusion of both money supply and money demand shocks, and these shocks were computed to fit the observed behavior of money and the price level. ${ }^{15}$

\footnotetext{
${ }^{15}$ This is the same procedure that underlies the analysis relating to Figure 13 . We add money demand innovations because this period was characterized by a strong rise in money velocity, i.e., the observed M1 contraction of around 12 percent over the period 1920:1-1921:1 was far too small to account for the 25 percent price decline that occurred over this period. The construction of this simulation conforms to the objective of assessing how the price decline would have affected real activity if it had in fact been unanticipated.
} 


\subsection{Contrasting 1920-21 with 1929-33}

There is evidence that there were considerable differences between the two periods: in the extent to which the price declines were anticipated, and in the sensitivity of nominal wages to the downturn in activity. These factors may have played a large role in accounting for pronounced differences in the behavior of real activity.

First, it seems likely that the disinflation experienced in 1920-21 had a much larger anticipated component. Previous major wars, including the War of 1812 and the Civil War, were followed by large deflations. The monetary authorities were committed to a return to gold convertibility at the original parity following wartime suspensions of gold convertibility (Bordo and Kydland 1995). World War I set the stage for a similar experience during this period; the U.S. price level more than doubled between 1914 and early 1920. It was clear to contemporaries of the period that a large deflation was required to restore the real price of gold to its prewar level at the original parity. It also seems that most observers would have expected (correctly) that the United States had a strong commitment to restoring the prewar relationship between prices and the price of gold. As noted by Friedman and Schwartz (1963), the flexible exchange rates that prevailed during the early interwar period "were regarded as a transitory expedient pending a return to gold, and monetary authorities everywhere sought to facilitate a return to fixed parities. (p. 236)" Accordingly, the major source of uncertainty about the deflation in the period immediately preceding the monetary tightening probably regarded its timing. Once the Federal Reserve raised the discount rate by 200 basis points between November 1919 and February 1920, there could have been little 
doubt about the Federal Reserve's commitment to deflate, or that a large disinflation would ensue. $^{16}$

A second consideration that may account for the less persistent real effects of the price decline in the 1920-21 recession compared to the Great Depression period is that wage setting appears to have been much more responsive to the downturn in economic conditions during the earlier period. Economists writing during the depression period noted the pronounced differences in wage adjustment across the two episodes, a subject examined more recently in work by O'Brien (1989). O'Brien (1989) not only provides strong evidence that wages became less responsive to aggregate demand between the 1920-21 recession and the late 1920 s, but that the change was recognized by contemporaries of the period and reflected a conscious change in wage-setting practices at the firm level designed to mollify the adverse effects of wage declines on household purchasing power. O'Brien observes that the view became widely held during the interwar period that rapid wage adjustment during the 192021 recession contributed markedly to the recession's severity. He argues that this philosophy encouraged collusive behavior on the part of major employers to not cut nominal wages for a significant time period after the onset of the Depression. O'Brien notes that certain major employers, such as General Motors and International Harvester, left nominal wage rates unchanged until the fall of 1931, two years into the downturn. Finally, the context of the two periods suggests a change in wage setting behavior. The extreme price fluctuations during the 1920-21 period would have encouraged, or perhaps forced, great wage flexibility.

\footnotetext{
${ }^{16}$ The February 1920 increase in the discount rate was the "sharpest single rise in the entire history of the System." Friedman and Schwartz 1963, p. 230.
} 
The Great Depression, however, followed almost a decade of price stability.

\subsection{0-21 revisited}

Figures 25 and 26 assess whether alternative assumptions about price expectations and wage adjustment during the 1920-21 period may help account for the much smaller output decline that occurred. Figure 25 performs a simulation of the model under the assumption that the price decline became fully anticipated as of $1920: 2$, that is, the quarter after the price level peaked, and shortly after the monetary tightening began. As in the corresponding perfect foresight simulation run over the Depression period in Figure 21, the figure is based on simulating the Taylor wage setting component of the model only, taking the capital stock's actual path as known. The figure indicates that if the price decline became fully anticipated by the time prices actually began to fall, the output effects would have only been about half as large as implied by the simulation in figure 24 - though still somewhat larger than what actually took place.

Figure 26 repeats the simulation in figure 25, except that wage adjustment is assumed to occur considerably more rapidly than in the parameterization of the $1929-36$ period. In particular, we set $\gamma=-0.5$, implying that the effect of price level innovations on output have a half-life of about half as long as in our 1929-36 parameterization. The figure implies that output would have only declined by about 16-17 percent (given the price level decline that actually occurred), reasonably close to the magnitude observed.

These simulations make it more apparent why a quantitative general equilibrium model 
is useful for evaluating the sticky wage hypothesis. Our results suggest that it is not enough to argue that the massive price decline that occurred during the Great Depression period caused the decline via a sticky wage channel. Rather, our results suggest that the unanticipated character of the price decline probably played an important role in explaining why the downturn was so large. Furthermore, it is evident that while this hypothesis is appealing insofar as it can match the downturn in major macroaggregates and the behavior of real wages, it does require that monetary shocks have highly persistent output effects. Nevertheless, this degree of persistence is consistent with the endogenous behavior of wages during the period. Finally, a comparison with the 1920-21 recession further highlights the 1929-36 period as an outlier experience: a similar-sized price decline had much smaller output effects during the earlier downturn, probably because a much larger fraction of the price decline was anticipated in 1920-21.

\section{Conclusions}

Our paper has focused on the ability of a particular hypothesis about how monetary shocks affect real activity - namely, through a sticky wage channel - to explain the magnitude and persistence of the Depression in the United States. Our results suggest that money operating through a sticky wage channel played a quantitatively significant role in accounting for the behavior of major macroaggregates over the downturn phase of the Depression. The version of the model with Taylor contracts is surprisingly successful in accounting for the behavior of output, consumption, hours worked and investment. In addition, the mechanism through 
which the sticky wage model predicts that a monetary decline would affect these variables seems consistent with the data. This is especially reflected in the model's ability to account for the behavior of real wages over the downturn.

While it is of course likely that other factors discussed in the introduction played a role in the downturn, the quantitative success of the simple model we consider is intriguing. Moreover, the sticky wage model's ability to account for the rise in real wages, in addition to the behavior of the macroaggregates, may provide an important basis for discriminating between alternative hypotheses about the causes of the downturn. This is because it is not apparent that other hypotheses would yield predictions consistent with observed real wage behavior, even if they could provide a satisfactory account of the macroaggregates.

Our model simulations and sensitivity analysis suggest that both the absolute severity of the Great Depression's downturn and its relative severity compared to the 1920-21 recession were in large part attributable to the price decline having a much larger unanticipated component during the Depression, and also to much less flexible wage-setting practices. These results seem to be an important refinement to the sticky wage explanation for the downturn. The findings are in line with both Hamilton's (1992) results that show a substantial component of the price decline to be unanticipated, and with O'Brien's (1989) work that indicates wage-setting became much less flexible during the course of the 1920 s.

Within the context of our sticky wage model, however, our results cast serious doubts on explanations of the recovery phase of the Depression which rely critically on the substantial remonetization that began in 1933 . The most serious evidence against this explanation is 
its counterfactual prediction that remonetization should have reduced real wages, stimulated labor demand, and allowed output to recover. By contrast, the data indicate that real wages rose substantially beginning in mid-1933, as nominal wages rose even more rapidly than prices, and that hours worked recovered much more slowly than output. While there is some industry and aggregate evidence that positive supply shocks played a role in allowing the economy to gradually recover despite some large exogenous increases in real wages due to legislative programs, providing a convincing account of the factors most responsible for the recovery continues to be an important topic for further research. 


\section{References}

1. Balke, Nathan S. and Robert J. Gordon. Appendix B, Historical Data, in Robert J. Gordon, ed., The American Business Cycle: Continuity and Change. Chicago: University of Chicago Press: 781-850 (1986).

2. Beney, M. Ada. Wages, Hours, and Employment in the United States 1914-36. New York: National Industrial Conference Board, Inc., 1936.

3. Bernanke, Ben. "Nonmonetary effects of the Financial Crisis in the Propagation of the Great Depression." American Economic Review 73 (June 1983), 257-76.

4. Bernanke, Ben. "The Macroeconomics of the Great Depression: A Comparative Approach." Journal of Money, Credit and Banking 27: 1-28 (1995).

5. Bernanke, Ben, and Kevin Carey. "Nominal Wage Stickiness and Aggregate supply in the Great Depression." Quarterly Journal of Economics 111: 853-884 (1996).

6. Blanchard, Olivier J., and Charles Kahn, "The Solution of Linear Difference Equations Under Rational Expectations," Econometrica 48: 1305-1313 (1980).

7. Bordo, Michael D. "The Contribution of 'A Monetary History of the United States, 1867-1960' to Monetary History," in Money, History, and International Finance: Essays in Honor of Anna J. Schwartz. Edited by M.D. Bordo, Chicago: University of Chicago Press, 1989, 15-70. 
8. Bordo, Michael D. and Finn Kydland. "The Gold Standard as a Rule: An Essay in Exploration." Explorations in Economic History 32: $423-464$ (1995).

9. Bordo, Michael D., Ehsan Choudhri and Anna J. Schwartz. "Could Stable Money Have Averted the Great Depression." Economic Inquiry, 33: 484-505 (1995).

10. Bresnahan, Timothy F. and Daniel M.G. Raff. "Interindustry Heterogeneity and the Great Depression: The American Motor Vehicle Industry, 1929-35." Journal of Economic History 7: 61-85 (1993).

11. Calomiris, Charles. "Financial Factors in the Great Depression." Journal of Economic Perspectives 7 (Spring 1993), 61-85.

12. Cecchetti, Stephen G. "Prices and the Great Depression: Was the Deflation of 1930-32 Really Unanticipated?" American Economic Review 82: 141-156 (1992).

13. Cecchetti, Stephen G. and Georgios Karras. "Sources of Output Fluctuations during the Interwar Period: Further Evidence on Causes of the Great Depression." Review of Economics and Statistics 76: 80-102 (1994).

14. Cho, Jang-Ok and Louis Phaneuf. "A Business Cycle Model with Nominal Wage Contracts and Government." Institute for Empirical Macroeconomics Discussion paper \#80, February 1993.

15. Crucini, Mario and James Kahn. "Tariffs and Aggregate Economic Activity: Lessons from the Great Depression." Journal of Monetary Economics 38: 427-467 (1996). 
16. Eichengreen, Barry. Golden Fetters: The Gold Standard and the Great Depression, 1929-1939. New York: Oxford University Press, 1992a.

17. Eichengreen, Barry. "The Origins and Nature of the Great Slump Revisited." Economic History Review (May 1992b), 213-39.

18. Eichengreen, Barry and Jeffrey Sachs. "Exchange Rates and Economic Recovery in the 1930s." Journal of Economic History 45 (1985), 925-46.

19. Evans, Martin and Paul Wachtel. "Were Price Changes During the Great Depression Anticipated? Evidence from Nominal Interest Rates." Journal of Monetary Economics 32: 3-34 (1993).

20. Fischer, Stanley. "Long-term Contacts, Rational Expectations, and the Optimal Money Supply Rule." Journal of Political Economy 85, 191-205 (1977).

21. Fisher, Irving. "The Debt Deflation Theory of the Great Depression." Econometrica 1: $337-357(1933)$.

22. Friedman, Milton and Anna J. Schwartz. A Monetary History of the United States, 1867-1960. Princeton: Princeton University Press, 1963.

23. Hamilton, James D. "Was the Deflation During the Great Depression Anticipated? Evidence from the Commodity Futures Market." American Economic Review 82: $157-178(1992)$. 
24. Hanes, Christopher. "Bargaining Power and Nominal Wage Rigidity in the Downturn of 1893, 1929, and 1981." Unpublished manuscript, University of Pennsylvania, 1995a.

25. Hanes, Christopher. "Changes in the Cyclical Behavior of Real Wages, 1870-1990." Unpublished manuscript, University of Pennsylvania, 1995b.

26. King, Robert G. "Money and Business Cycles." Unpublished manuscript, 1990.

27. Meltzer, Allan H. "Monetary and Other Explanations of the Start of the Great Depression." Journal of Monetary Economics 2 (1976), 455-471.

28. Mishkin, Frederic S. "The Household Balance Sheet and the Great Depression." Journal of Economic History (December 1978), 918-37.

29. O'Brien, Anthony P. "A Behavioral Explanation for Nominal Wage Rigidity during the Great Depression." Quarterly Journal of Economics 104: 719-736 (1989).

30. Romer, Christina. "The Great Crash and the Onset of the Great Depression." Quarterly Journal of Economics (August 1990), 597-624.

31. Romer, Christina. "What Ended the Great Depression?" Journal of Economic History $52(1992), 757-84$.

32. Romer, Christina. "The Nation in Depression." Journal of Economic Perspectives 7 (Spring 1993), 19-40.

33. Taylor, John B. "Aggregate Dynamics and Staggered Contracts." Journal of Political Economy 88: 1-23 (1980). 
34. Temin, Peter. Did Monetary Forces Cause the Great Depression? New York: W.W. Norton, 1976.

35. Temin, Peter. Lessons from the Great Depression. Cambridge, MA: MIT Press, 1989.

36. United States Department of Commerce, Bureau of Economic Analysis. Fixed Reproducible Tangible Wealth in the United States. 1990.

37. Weinstein, Michael M. "Some Macroeconomic Impacts of the National Industrial Recovery Act, 1933-1935." In Karl Brunner (ed.) The Great Depression Revisited. Boston: Martinus Nighoff: 262-281 (1981). 

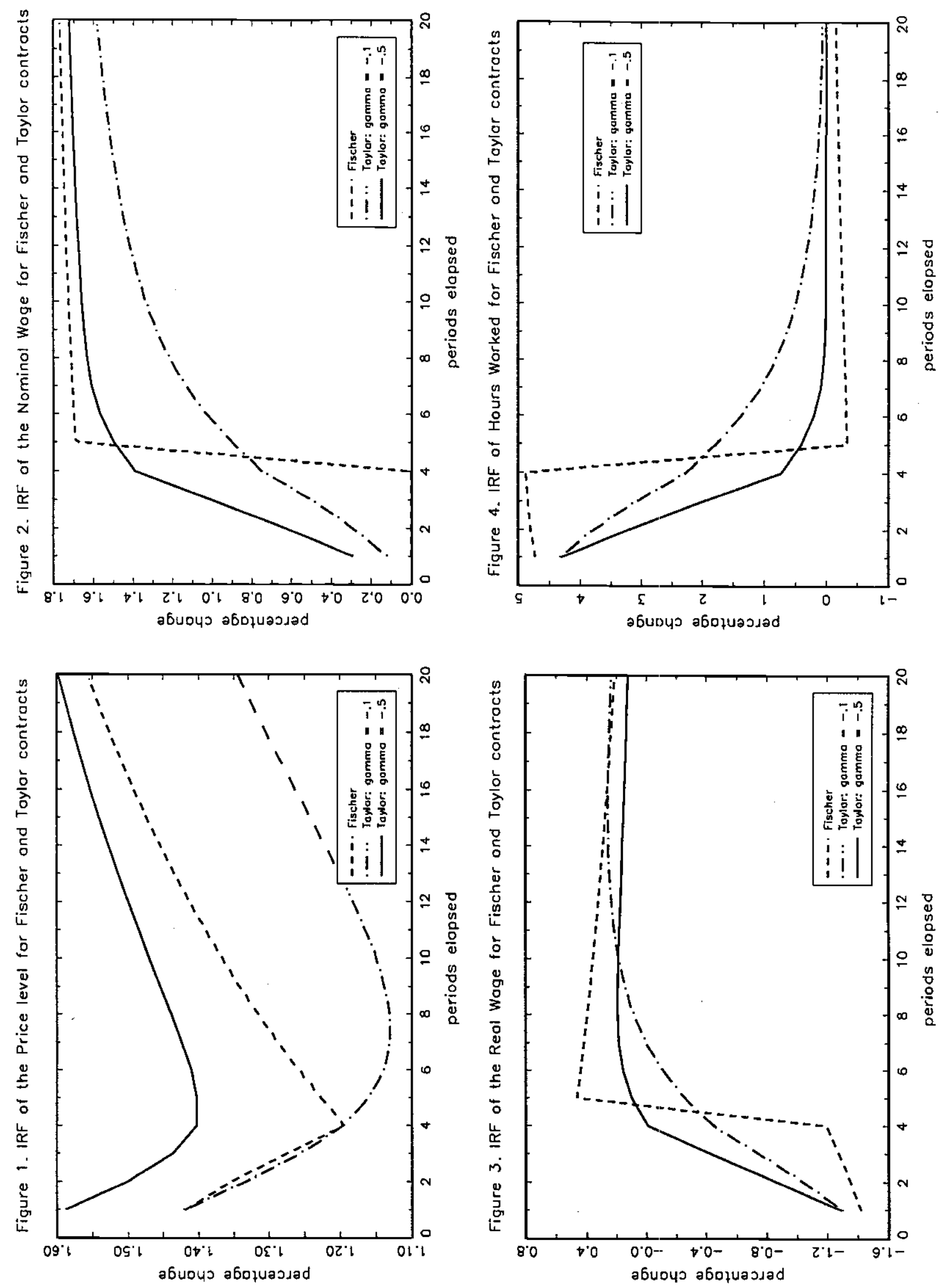
Figure 5. IRF af Output for Fischer and Taylor cantracts

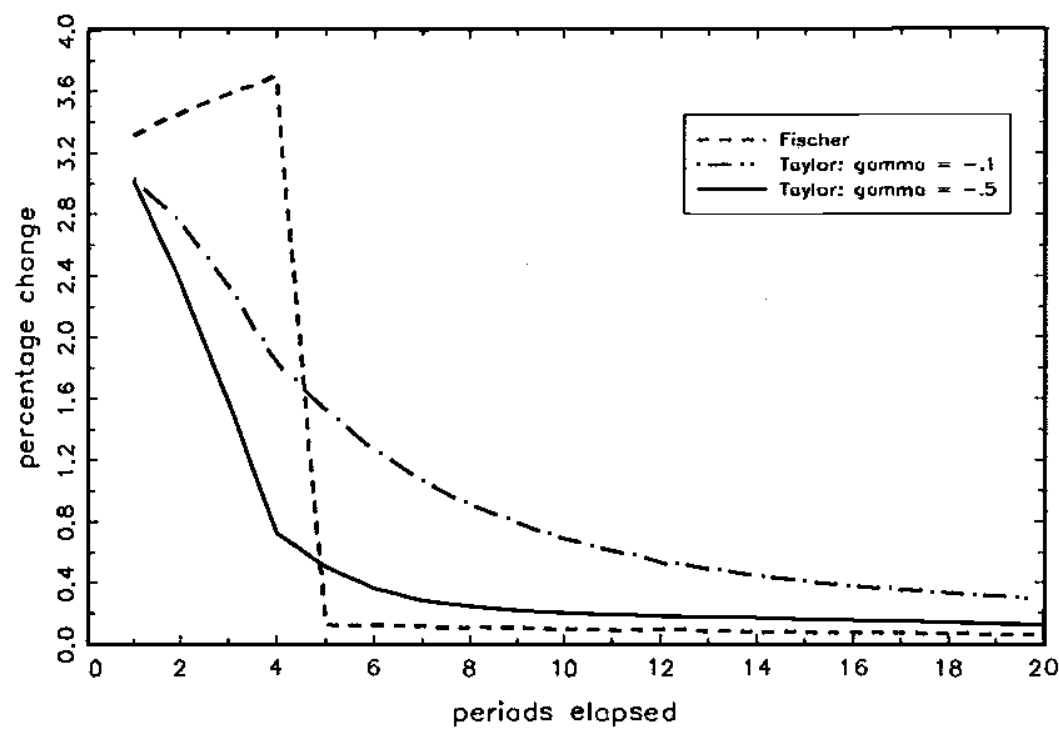

Figure 7. IRF of Investment for Fischer and Taylor contracts

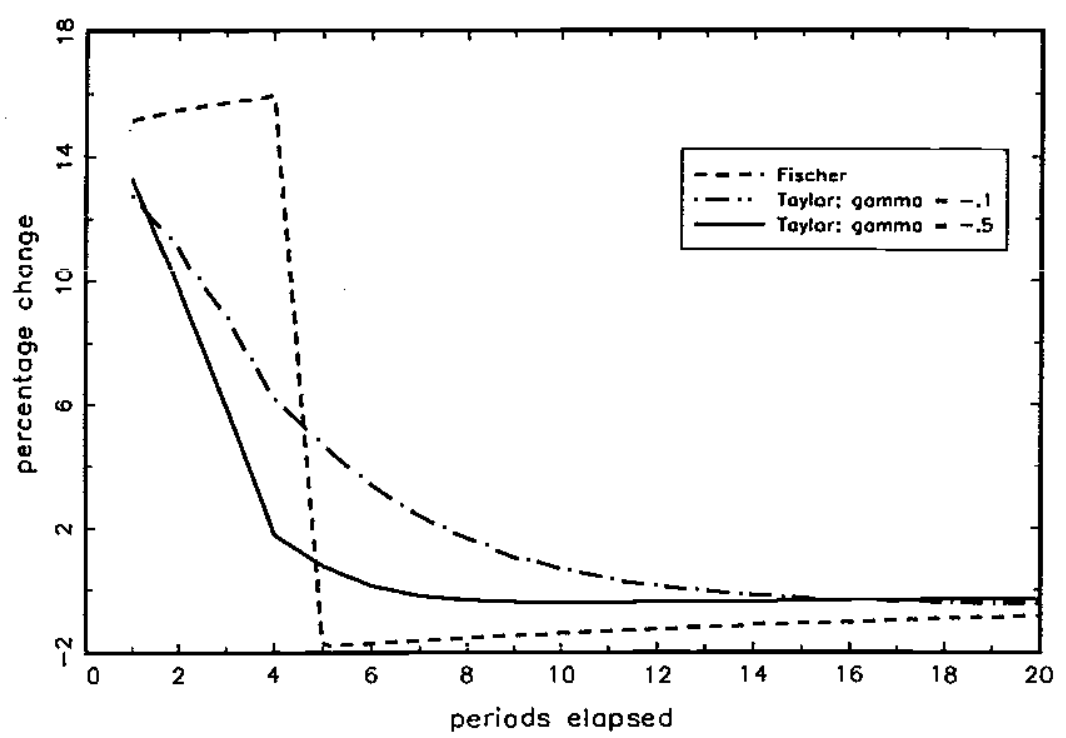

Figure 6. IRF of Consumption for Fischer ond Taylor controcts

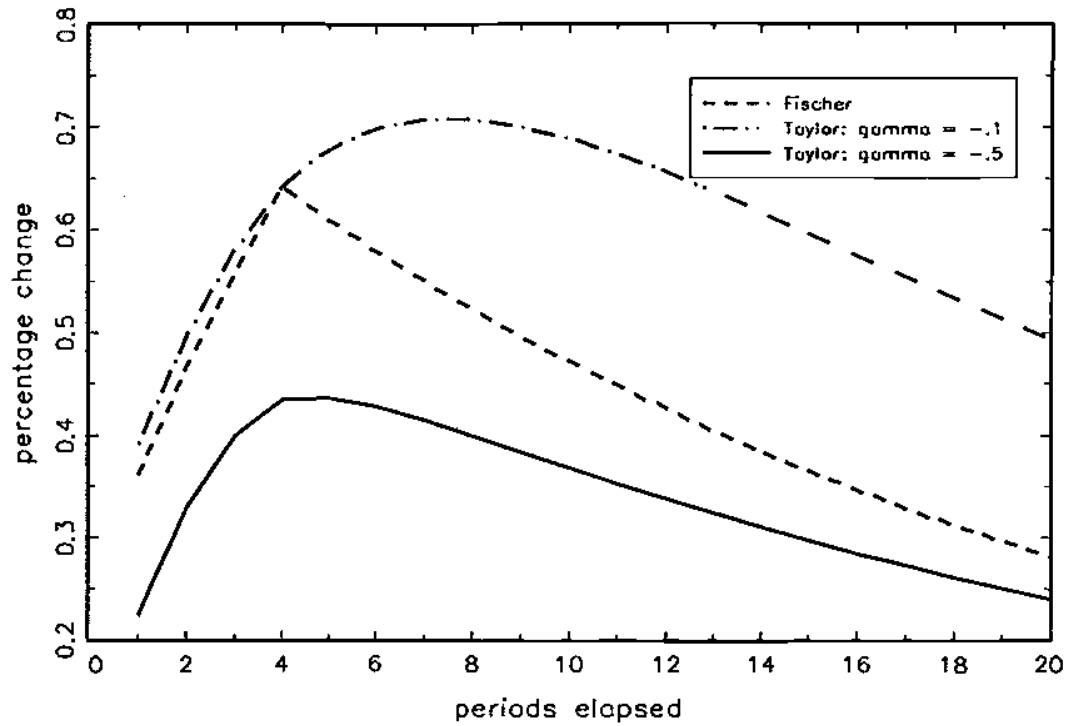

Figure 8. Money Growth Innovation, 1929:1-1936:4

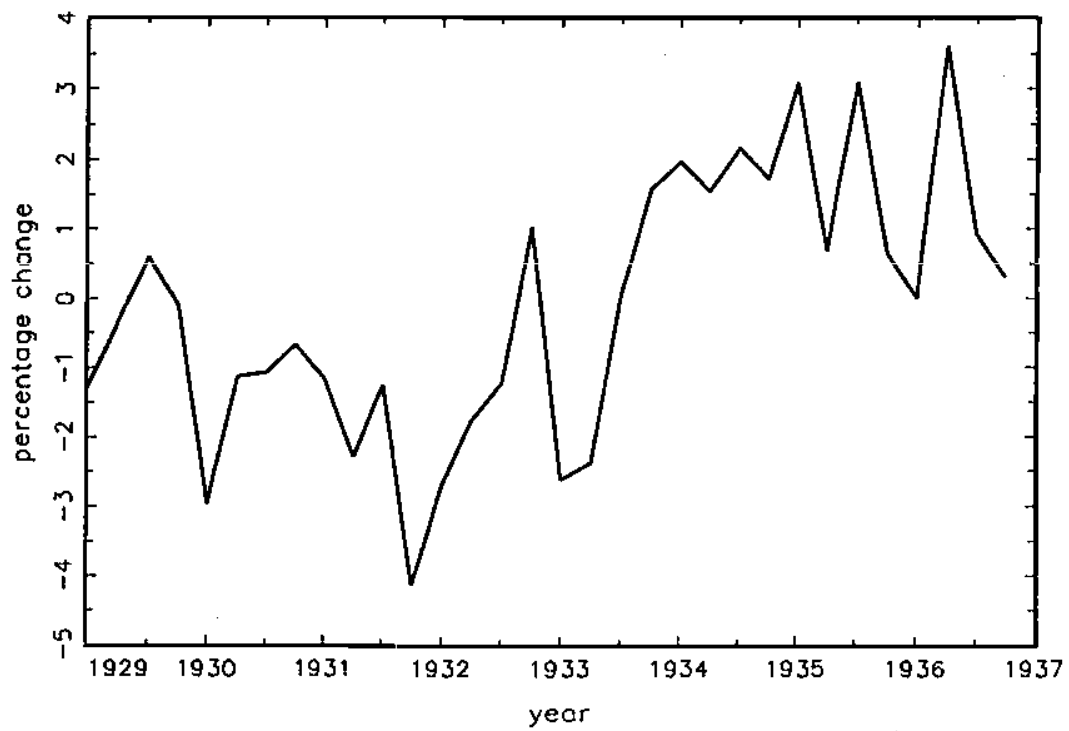



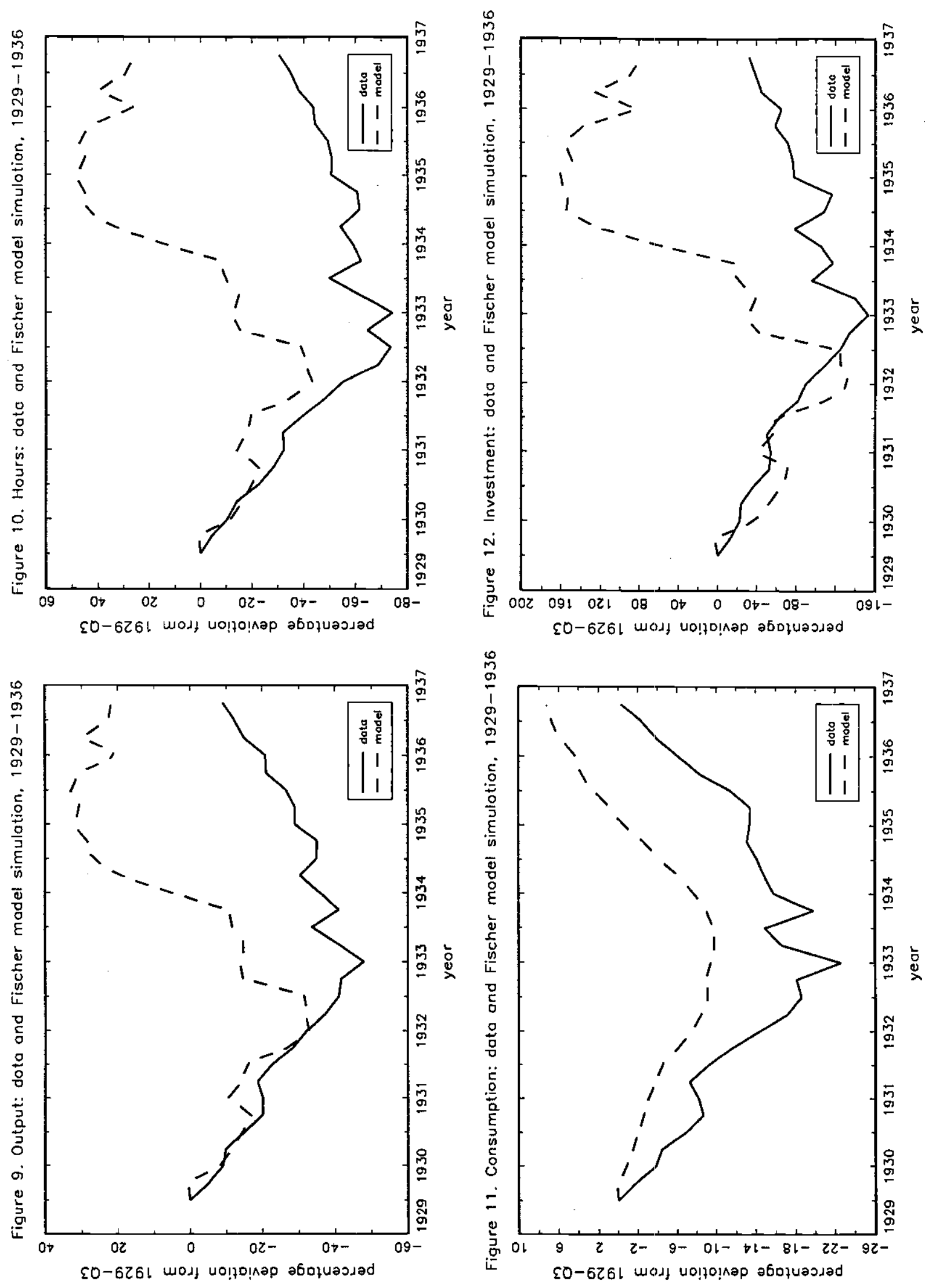


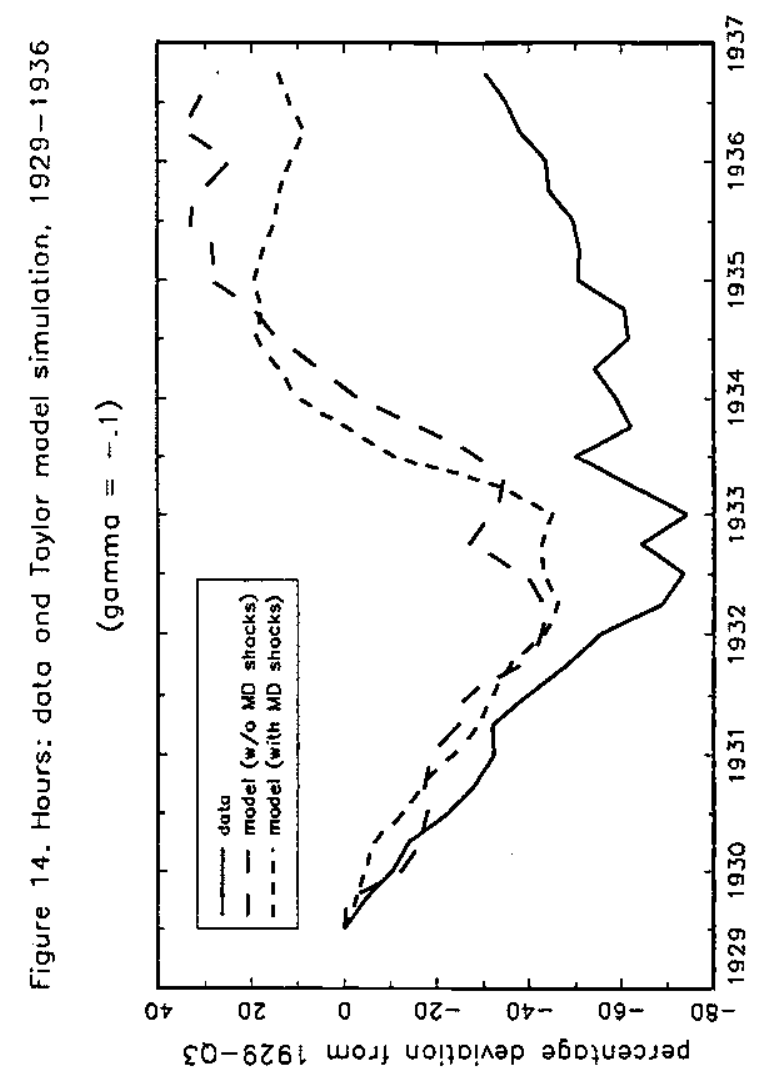

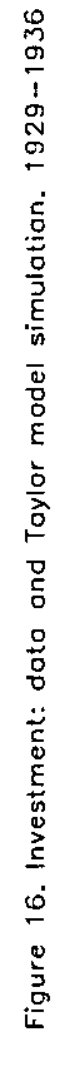
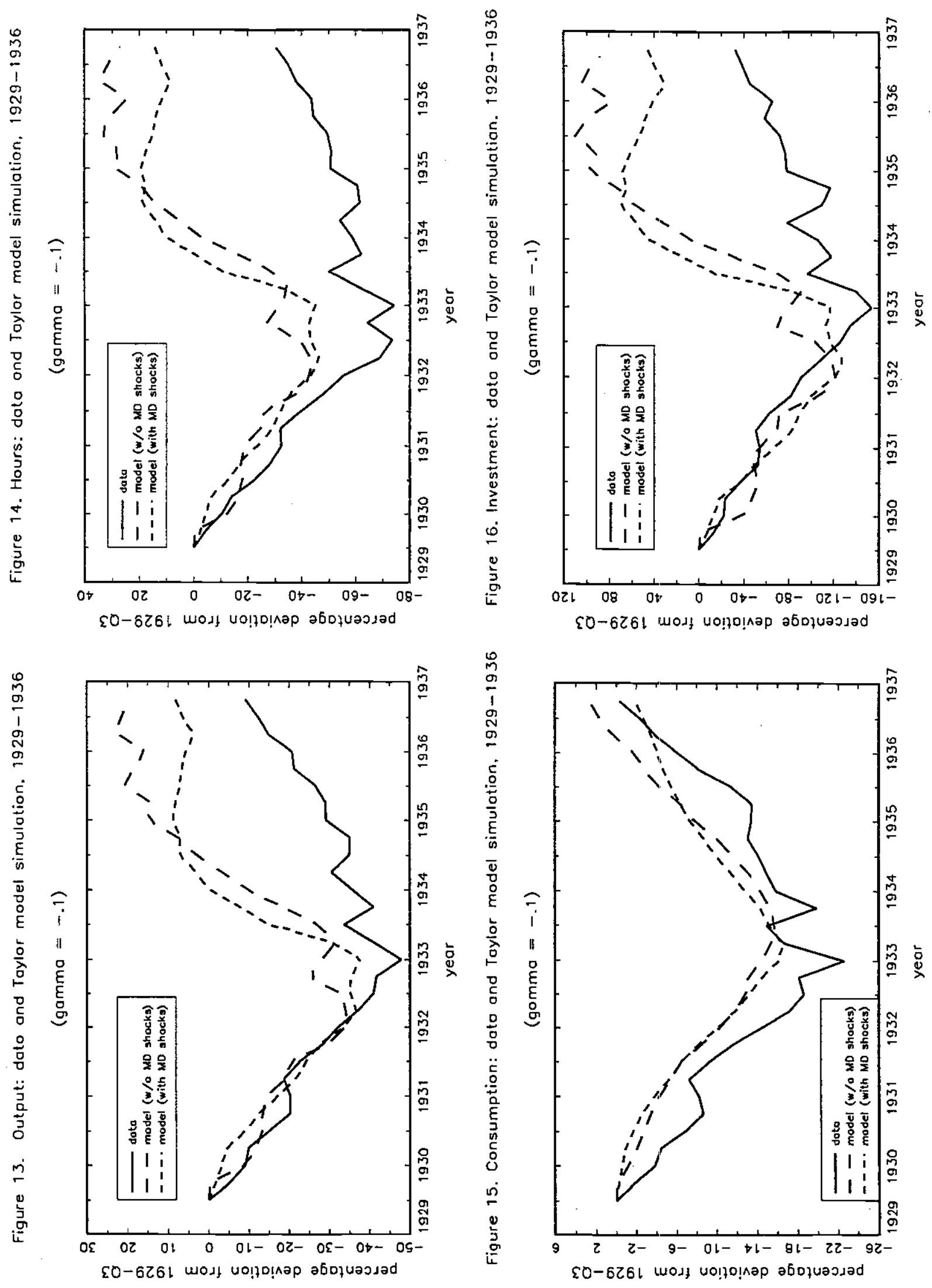
Figure 17. Price level: doto and Toylor model simulation, 1929-1936

$($ gammo $=-.1)$

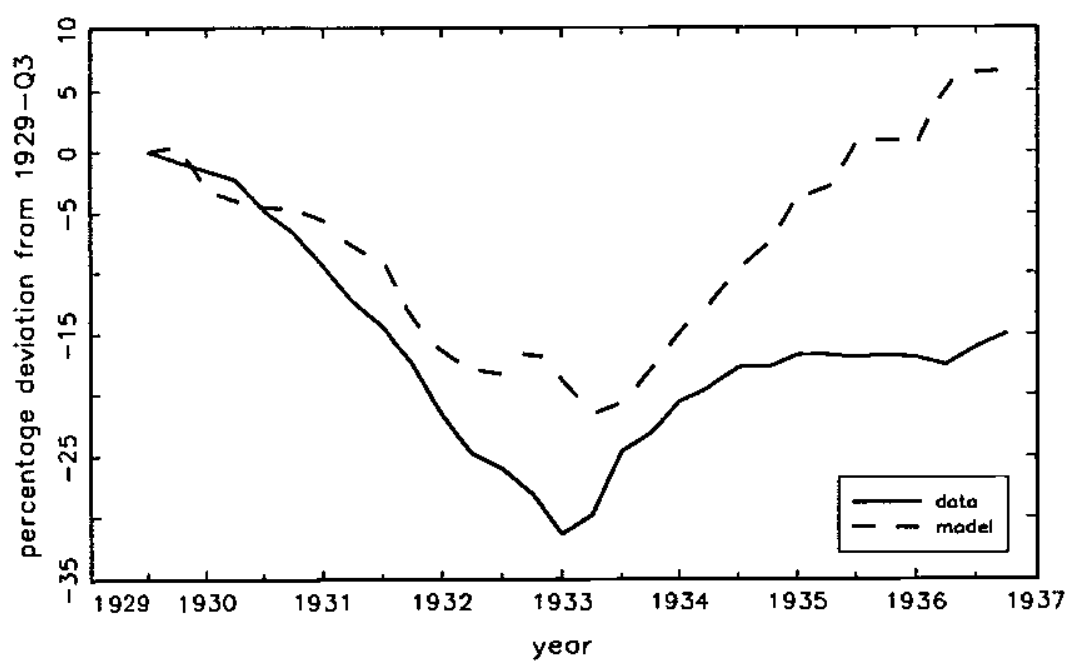

Figure 19. Nominol woge: doto and Toylor model simulation, 1929-1936 (gommo $=-.1$, model with money demond shocks)

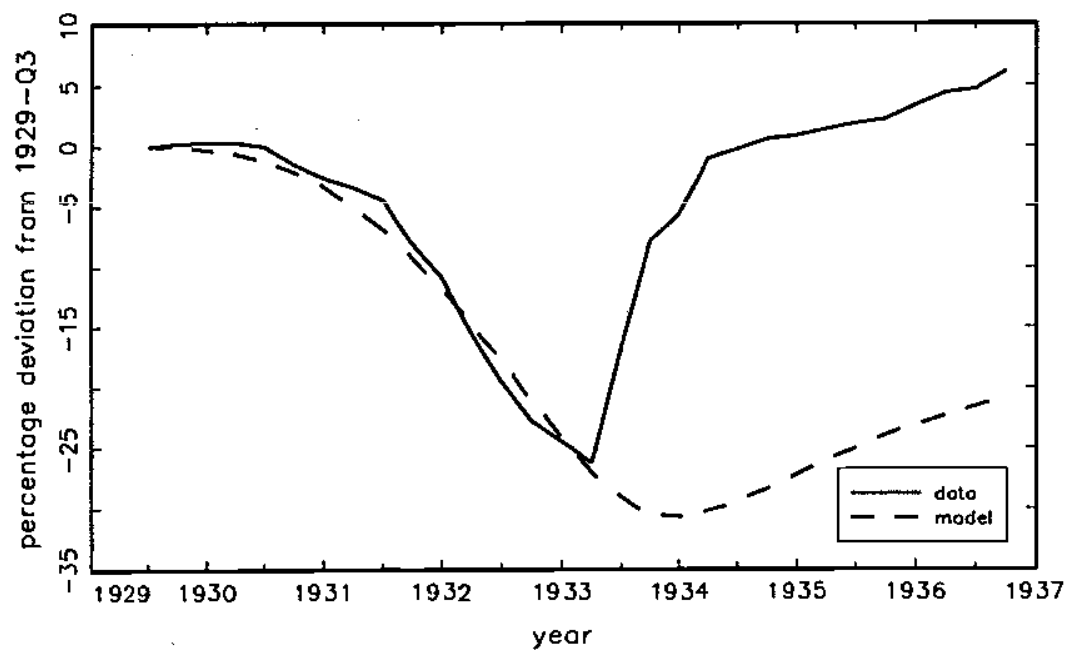

Figure 18. Real Wages: dato ond Taylor model simulotion, 1929-1936 (gommo $=-.1$ model with money demond shocks)

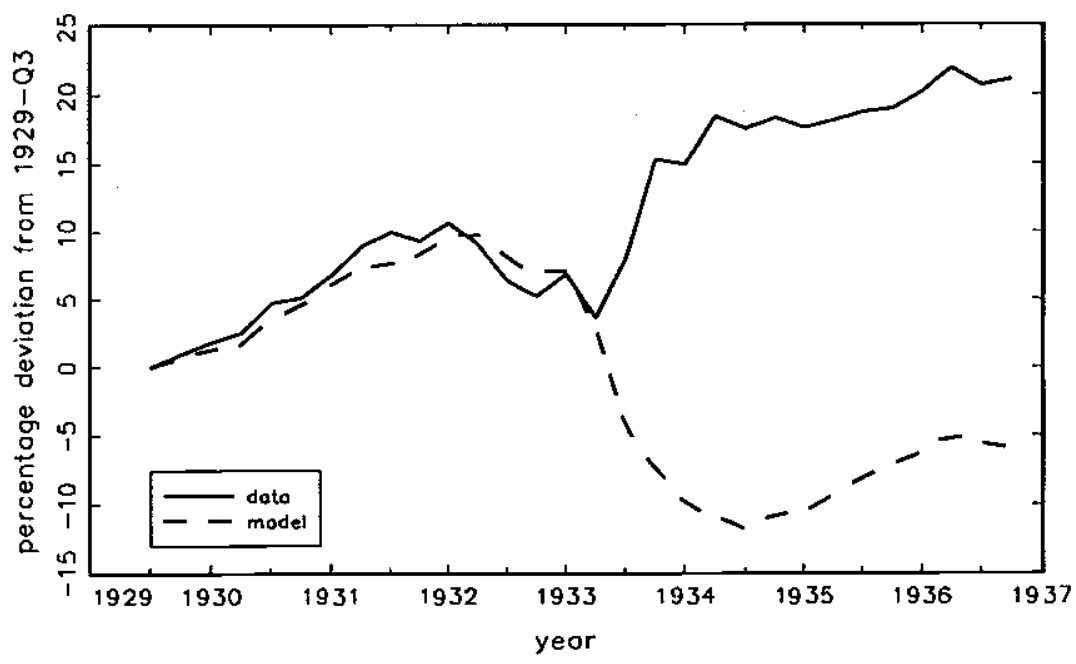

Figure 20, Output: doto and Taylor model simulotion, 1929-1936 (gommo $=-.03$, model with money demand shocks)

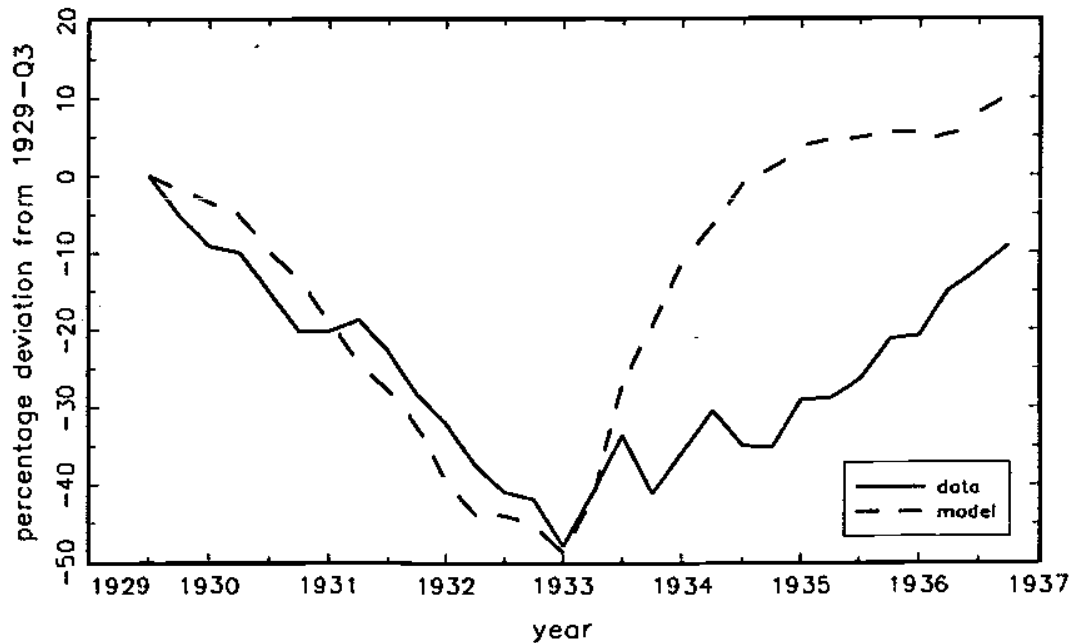



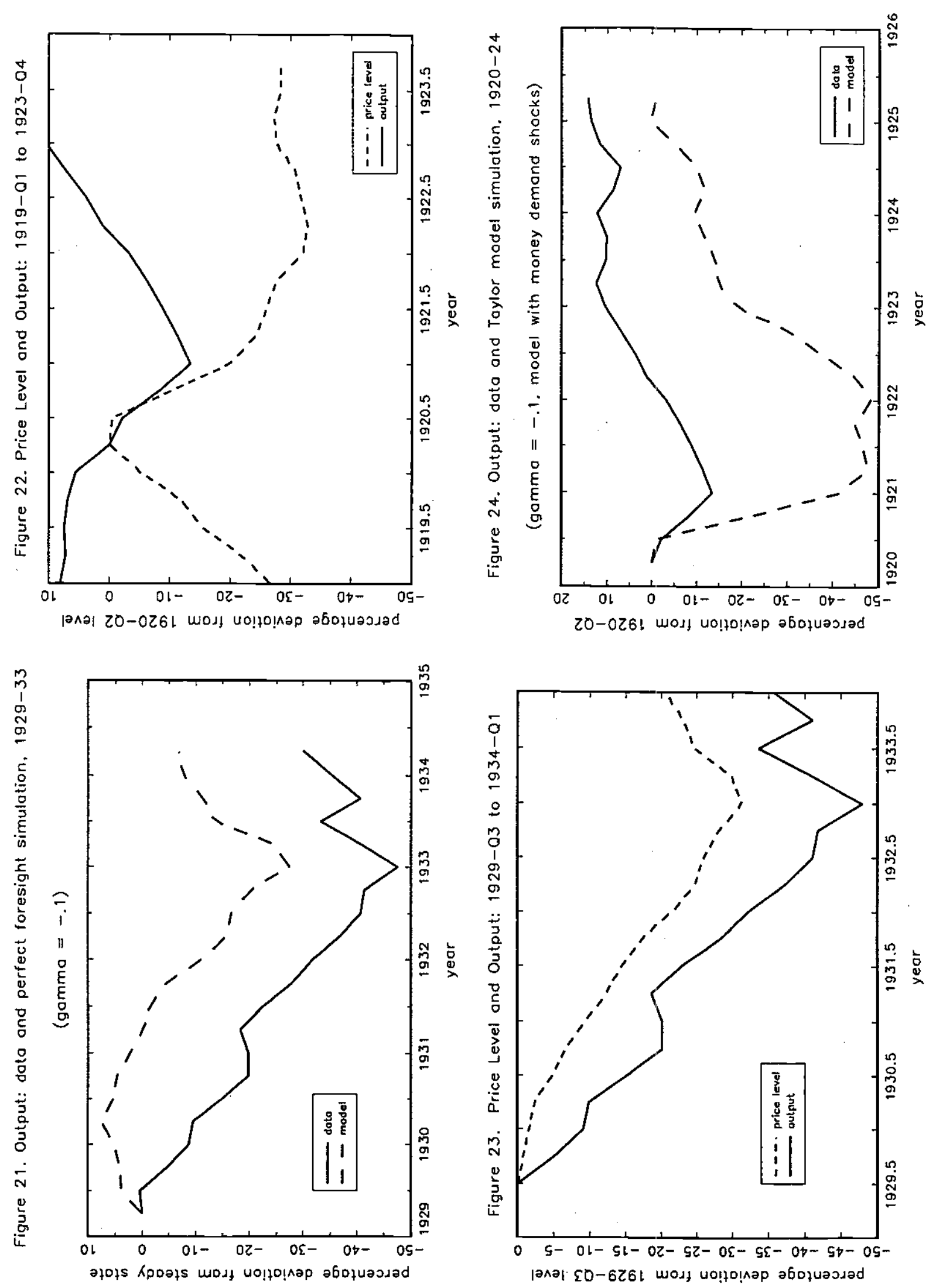

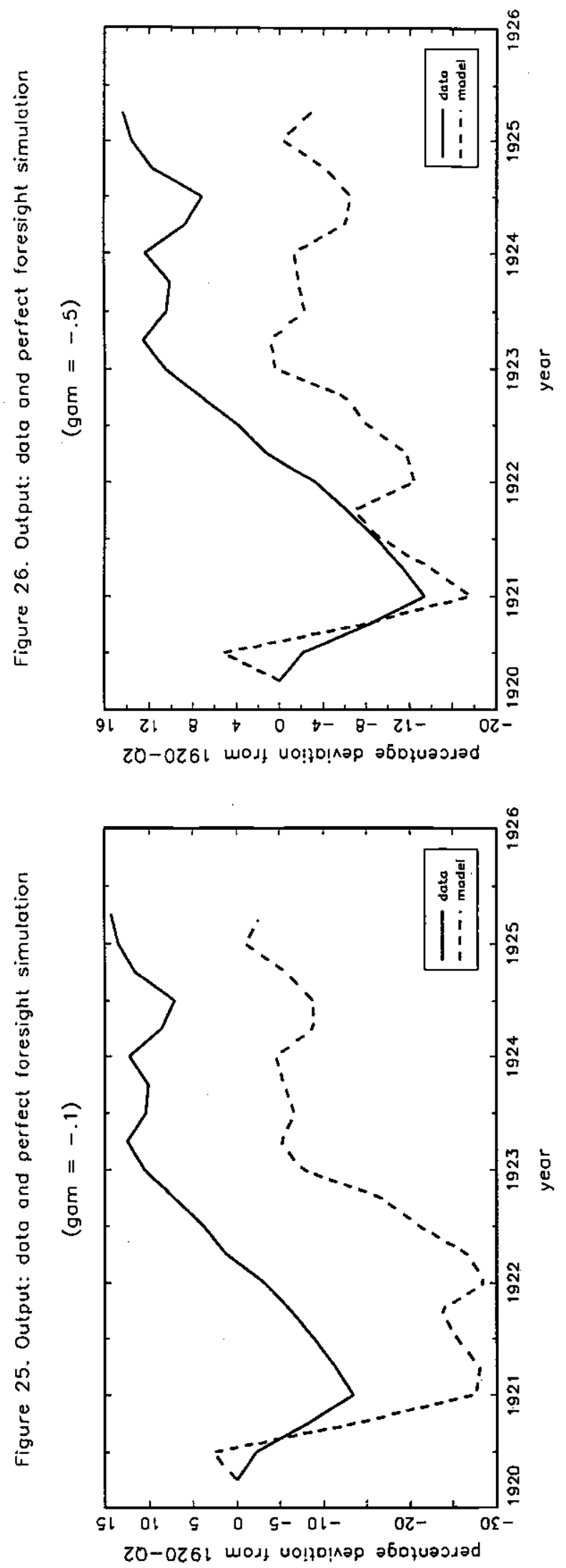